OPEN ACCESS

Edited by:

László Kredics,

University of Szeged, Hungary

Reviewed by:

Manikandan Palanisamy

Majmaah University, Saudi Arabia

Ilona Dóczi,

University of Szeged, Hungary

Macit Ilkit,

Çukurova University, Turkey

*Correspondence:

Pavel Žák pavel.zak@fnhk.cz: zak.pce@email.cz

Specialty section:

This article was submitted to Fungi and Their Interactions,

a section of the journal

Frontiers in Microbiology

Received: 06 May 2019

Accepted: 09 September 2019

Published: 29 October 2019

Citation:

Buchta V, Bolehovská R, Hovorková E, Cornely OA, Seidel $D$ and Žák P (2019) Saprochaete clavata Invasive Infections - A New

Threat to Hematological-Oncological Patients. Front. Microbiol. 10:2196. doi: 10.3389/fmicb.2019.02196

\section{Saprochaete clavata Invasive Infections - A New Threat to Hematological-Oncological Patients}

\author{
Vladimir Buchta ${ }^{1}$, Radka Bolehovská2, Eva Hovorková ${ }^{3}$, Oliver A. Cornely ${ }^{4,5,6}$, \\ Danila Seidel ${ }^{4,7}$ and Pavel Žák ${ }^{8 *}$
}

\begin{abstract}
'Department of Clinical Microbiology, Faculty of Medicine in Hradec Králové, Faculty Hospital in Hradec Králové, Charles University in Prague, Hradec Králové, Czechia, ${ }^{2}$ Department of Clinical Biochemistry and Diagnostics, Faculty of Medicine in Hradec Králové, Faculty Hospital in Hradec Králové, Charles University in Prague, Hradec Králové, Czechia, ${ }^{3}$ The Fingerland Department of Pathology, Faculty of Medicine in Hradec Králové, Faculty Hospital in Hradec Králové, Charles University in Prague, Hradec Králové, Czechia, ${ }^{4}$ Cologne Excellence Cluster on Cellular Stress Responses in Aging-Associated Diseases (CECAD), University of Cologne, Cologne, Germany, ${ }^{5}$ Department I of Internal Medicine ECMM Diamond Center of Excellence in Medical Mycology, German Centre for Infection Research (DZIF), University of Cologne, Cologne, Germany, ${ }^{6}$ Clinical Trials Centre Cologne (ZKS Köln), University of Cologne, Cologne, Germany, ${ }^{7}$ Department of Internal Medicine, ECMM Diamond Center of Excellence in Medical Mycology, University of Cologne, Cologne, Germany, ${ }^{8}$ th Department of Internal Medicine - Division of Hematology, Faculty of Medicine in Hradec Králové, Faculty Hospital in Hradec Králové, Charles University in Prague, Hradec Králové, Czechia
\end{abstract}

Background: Saprochaete clavata (formerly Geotrichum clavatum, now proposed as Magnusiomyces clavatus) is a filamentous yeast-like fungus that has recently been described as an emerging pathogen mostly in patients with acute leukemia.

Methods: This is a retrospective study of patients diagnosed with proven and probable S. clavata infection at the University Hospital, Hradec Králové, Czechia between March 2005 and December 2017. Previous cases were identified from the literature and FungiScope ${ }^{\circledast}$ database.

Results: Six new cases (5 females, 1 male) of blood-stream S. clavata infections at the hemato-oncological department were described including epidemiological data of additional 48 patients colonized with the species. Overall, 116 strains of S. clavata were isolated from different clinical specimens of 54 patients; most of them belonged to the respiratory tract (60.3\%). S. clavata was the most frequent species among arthroconidial yeasts (Trichosporon, Galactomyces, Magnusiomyces) recovered from the blood. All our patients with S. clavata infection had profound neutropenia, a central venous catheter, broad-spectrum antibiotics and antifungal prophylaxis; four had a history of a biliary tract system disease. The diagnosis was based on a positive blood culture in all patients. Four patients died of multiorgan failure and sepsis despite treatment with lipid-based amphotericin B and/or voriconazole. From the literature and FungiScope database, 67 previous cases of $S$. clavata infections were evaluated in context of our cases. 


\begin{abstract}
Conclusion: Saprochaete clavata infection represents a life-threatening mycosis in severely immunocompromised patients. The successful outcome of treatment seems to be critically dependent on the early diagnosis and the recovery of underlying conditions associated with immune dysfunction or deficiency.
\end{abstract}

Keywords: Saprochaete, Magnusiomyces, Geotrichum, leukemia, fungemia, diagnosis, therapy, FungiScope ${ }^{\mathrm{TM}}$

\section{INTRODUCTION}

Invasive systemic infections caused by fungi have increasingly been recognized and represent relevant cause of mortality and morbidity in growing segment of immunocompromised patients for the last decades (Miceli et al., 2011; Armstrong-James et al., 2017). The predisposing conditions are largely associated with changing spectrum of patients (age structure, co-morbidities) who are associated with a more risky therapeutic management such as an extensive surgery or aggressive treatment modalities. The majority of these risk factors are related to impaired immune defense mechanisms (hematological malignancies and transplantations, neutropenia, immunodeficiency, HIV), often as a result of the use of immunosuppressant drugs (e.g., corticosteroids, cyclosporine, biologics), the disruption of skin and mucosa integrity (extensive surgery, catheterization, burns, mucositis), and interference of antibiotics with the indigenous microbiota (dysbiosis) (Gulcan et al., 2016; Vallabhaneni and Chiller, 2016; Vallabhaneni et al., 2016; Colombo et al., 2017). These conditions make patient population vulnerable to opportunistic pathogens including fungi such as Aspergillus, Candida, Cryptococcus or Mucorales (Vallabhaneni et al., 2016, 2017; Colombo et al., 2017). Apart from the main fungal etiology, there is a rare and taxonomically diverse group of opportunistic yeasts belonging to the genera Galactomyces, Trichosporon, and Magnusiomyces (Saprochaete), which share morphological characteristics, namely the production of arthroconidia (Hazen, 1995; Henrich et al., 2009; Repetto et al., 2012; Meletiadis and Roilides, 2013; Arendrup et al., 2014; Durán Graeff et al., 2017; Fernández-Ruiz et al., 2017). Most systemic infections caused by those arthroconidial fungi are attributable to two species, Magnusiomyces capitatus (synonym Saprochaete capitata) and Trichosporon asahii. Saprochaete clavata has emerged as a new pathogen in hematological patients in French and Italian hospitals (Lacroix et al., 2007; Camus et al., 2014; Picard et al., 2014; Vaux et al., 2014; Cornely et al., 2015; Del Principe et al., 2016; Favre et al., 2016; Esposto et al., 2018; Leoni et al., 2018). Taxonomy studies showed that $S$. clavata and $M$. capitatus are closely related (de Hoog et al., 1986; Guého et al., 1987; Smith and Poot, 1998). Today, three main clades of the arthroconidial genera are discriminated: Galactomyces and Dipodascus which are associated with the Geotrichum anamorphs, while Magnusiomyces with the Saprochaete species (De Hoog and Smith, 2004; Daniel et al., 2014). Recently, owing to the principle the one fungus, one name, dual naming has been replaced and M. capitatus (synonym S. capitata, Dipodascus capitatus) and S. clavata are now accepted (De Hoog and Smith, 2004; Hawksworth et al., 2011). In addition, Kaplan et al. (2017) have pointed out that the rules of nomenclature using the oldest valid name and the molecular phylogeny would necessitate renaming S. clavata to Magnusiomyces clavatus. Majority of characteristics of epidemiology, diagnosis and therapy of $S$. clavata infections are similar to those caused by $M$. capitatus and T. asahii (Kaplan et al., 2017). They include frequent recovery from blood, lack of specific diagnostic methods, no specific breakpoints for antifungal susceptibility test results and no optimal therapeutic regimen. Moreover, epidemiological data are scarce; there are only a few details about source and transmission of $S$. clavata, although it has the potential to cause outbreaks (Bougnoux et al., 2018).

Here, we present six new cases of severe infection caused by $S$. clavata diagnosed in the hematologic intensive care unit and epidemiological data of hospital recordings of 48 patients colonized with the yeast at the University Hospital, Hradec Králové, Czechia between March 2005 and December 2017, which are discussed in context of other $S$. clavata cases reported in the literature and international registry FungiScope ${ }^{\circledR}$.

\section{MATERIALS AND METHODS}

\section{Patient Information}

Clinical data of patients with diagnosed S. clavata infection were collected including basic demographics, underlying diseases, clinical picture, antifungal therapy, and clinical outcome (Table 1). Cases with probable or proven infection classified according to the EORTC/MSG criteria were included (De Pauw et al., 2008). A literature search using PubMed for respective cases was done with the search terms "Saprochaete," "Geotrichum," "Dipodascus," "Magnusiomyces," "fungemia," "invasive infection," and "rare mycoses." In addition, cases identified from the FungiScope ${ }^{\circledR}$ registry were selected (Seidel et al., 2017).

\section{Collection and Identification of Fungal Isolates}

All clinical specimens - cerebrospinal fluid, bronchoalveolar lavage (BAL) fluid, sputum, tracheal aspirate, urine, stool, wound swab, cervicovaginal fluid, punctate, skin adnexa, upper respiratory tract samples - obtained from patients hospitalized in University Hospital were routinely analyzed in mycological laboratory by inoculating onto mycological agar (SDA) to get individual colonies for further investigation such as biochemical tests (biochemical profile assessment), additional cultivation on Corn-meal agar (description of fungal micromorphology), antifungal susceptibility testing. Most of the conventional 
TABLE 1 | Baseline characteristics of Czech patients with Saprochaete clavata infection.

\begin{tabular}{|c|c|c|c|c|c|c|}
\hline & Patient 1 & Patient 2 & Patient 3 & Patient 4 & Patient 5 & Patient 6 \\
\hline Sex & Male & Female & Female & Female & Female & Female \\
\hline Age & 45 & 61 & 63 & 58 & 50 & 66 \\
\hline $\begin{array}{l}\text { Underlying present } \\
\text { disease }\end{array}$ & $\mathrm{AML}$ - late relapse & $\mathrm{AML}-$ new & $\mathrm{AML}-$ new & $\mathrm{AML}$ - early relapse & $\mathrm{AML}$ - late relapse & $\begin{array}{l}\text { DLBCL } \\
\text { Bile duct obstruction } \\
\text { Hemorrhagic shock } \\
\text { Candida glabrata septic shock }\end{array}$ \\
\hline $\begin{array}{l}\text { Previous diseases/Risk } \\
\text { factors }\end{array}$ & $\begin{array}{l}\text { AML (alloHSCT) } \\
\text { Acute GVHD } \\
\text { Cholelithiasis } \\
\text { Cholecystectomy } \\
\text { Common bile duct } \\
\text { obstruction (internal } \\
\text { biliary drainage) } \\
\text { HSV infection }\end{array}$ & $\begin{array}{l}\text { Cholelithiasis } \\
\text { Cholecystectomy } \\
\text { Chronic pancreatitis } \\
\text { Ovarial cystadenofibroma } \\
\text { (adnexectomy) }\end{array}$ & $\begin{array}{l}\text { Cholelithiasis } \\
\text { Cholecystectomy }\end{array}$ & $\begin{array}{l}\text { AML (1st alloHSCT) } \\
\text { Acute GvHD } \\
\text { Cervix ca in situ (hysterectomy) } \\
\text { Renal ca (resection) } \\
\text { Colorectal ca (resection, radio) } \\
\text { Chronical anal fissura Recurrent } \\
\text { CDI MDS-EB2 (Aza) }\end{array}$ & $\begin{array}{l}\text { HSV myocarditis } \\
\text { AML (autoHSCT) }\end{array}$ & $\begin{array}{l}\text { Cholelithiasis } \\
\text { Cholecystectomy }\end{array}$ \\
\hline Chemotherapy regimen & Ida-HiDAraC & $\begin{array}{l}\text { Chemotherapy } 3+7 \\
\text { FLAG-Ida }\end{array}$ & $\begin{array}{l}\text { 1st course Chemotherapy } \\
3+7 \text { 2nd course of HiDAC }\end{array}$ & $\begin{array}{l}\text { FLAG-Ida TBI 3Gy + F and 2nd } \\
\text { alloHSCT }\end{array}$ & Chemotherapy $3+7$ & $\begin{array}{l}\text { SoluMedrol and R-CHOP, } \\
\text { intrathecal (hydrocortisone, } \\
\text { MTX + AraC) }\end{array}$ \\
\hline \multicolumn{7}{|l|}{ Neutropenia (days) } \\
\hline ANC < 100/ml & 19 & 45 & 5 & 20 & 20 & 8 \\
\hline ANC $100-500 / \mathrm{ml}$ & 0 & 0 & 7 & 3 & 0 & 0 \\
\hline $\begin{array}{l}\text { Duration neutropenia } \\
\text { (days) ANC }<100 / \mathrm{ml} \text { at } \\
\text { the time positive culture }\end{array}$ & 14 & 33 & 7 & 12 & 8 & 3 \\
\hline Diabetes mellitus & No & No & No & Yes & No & No \\
\hline Mucositis & Yes, grade III & Yes, grade III & Yes, grade II & Yes, grade IV & Yes, grade II & No \\
\hline CVC & Yes & Yes & Yes & Yes & Yes & Yes \\
\hline Urinary catheter & Yes & Yes & No & Yes & Yes & Yes \\
\hline Nasogastric tube & Yes & Yes & No & Yes & Yes & Yes \\
\hline Pulmonary ventilation & Yes & Yes & No & No & No & Yes \\
\hline Parenteral nutrition & Yes & Yes & No & Yes & Yes & Yes \\
\hline \multicolumn{7}{|l|}{ Prophylaxis } \\
\hline Antibiotic & Ciprofloxacin & Ciprofloxacin & Ciprofloxacin & Ciprofloxacin & No & Ciprofloxacin \\
\hline Antiviral & Acyclovir & Acyclovir & No & Acyclovir & Acyclovir & No \\
\hline Antifungal & Fluconazole & Fluconazole & Fluconazole & Voriconazole & Fluconazole & Fluconazole \\
\hline \multirow[t]{6}{*}{ Antibiotic therapy } & Meropenem & Teicoplanin & Ciprofloxacin & Linezolid & Cephoperazone & Piperacillin/Taz \\
\hline & Vancomycin & Imipenem & Piperacillin/Taz & Meropenem & Meropenem & Meropenem Linezolid \\
\hline & Teicoplanin & Cephoperazone & Metronidazole & Levofloxacin & Teicoplanin & Vancomycin \\
\hline & & Piperacillin/Taz & & & Cefepime & Amikacin \\
\hline & & Vancomycin & & & & \\
\hline & & Amikacin & & & & \\
\hline
\end{tabular}




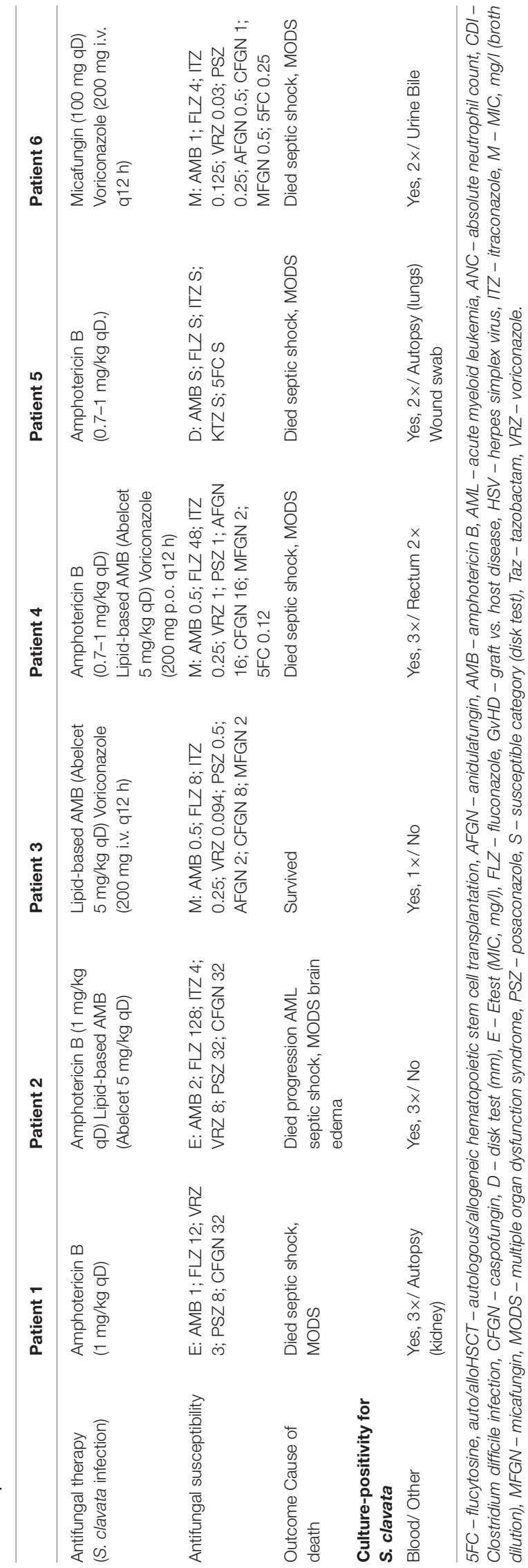

diagnostic methods were replaced after availability MALDI TOF mass spectrometry (protein profile assessment). Blood samples were cultivated in the BACTEC system using Mycosis medium or media for aerobic bacteria (Beckton Dickinson Diagnostic Instrument System). In case of BAL fluid, sputum, tracheal aspirate, and urine the samples were quantified after inoculation on SDA by means of calibrating bacteriological loops. Fungal identification including $S$. clavata was based on a combination of microscopic examination of morphological traits on Cornmeal agar, especially arthrospore formation (Figure 1), colony appearance on chromogenic agar (Colorex, Trios, Czechia), and biochemical pattern methods based on the evaluation of urease production, in-house carbon auxanogram assimilation tests (17 carbohydrates and sugar alcohols) (sugar disks provided by ITEST plus, Czechia), and/or using of the API ID32C test (BioMérieux, Czechia). Three blood isolates were additionally identified by MALDI-TOF mass spectrometry (Bruker).

Criteria for S. clavata identification included the formation of arthrospores, the absence of urease production, and assimilation of glucose, cellobiose, variable galactose, and negative xylose. These physiological characteristics seem to be sufficient for routine laboratory discrimination of the main arthroconidial fungi pathogenic for humans, especially between $M$. capitatus and S. clavata (Smith and Poot, 1998; Kaplan et al., 2017).

Isolates from Patient 3 and 4 were analyzed by sequencing. DNA was extracted from the strains using a QIAamp ${ }^{\circledR}$ DNA Mini Kit (Qiagen) protocol and the 18S rRNA gene was amplified using PCR (Millar et al., 2000). Sequences were analyzed using BLAST at $\mathrm{NCBI}^{1}$.

\section{Antifungal Susceptibility Testing}

The minimum inhibitory concentration (MIC) was determined using Etest (BioMérieux, Czechia) or Sensititre YeastOne (Trek Diagnostics, BioVendor, Czechia) following the instructions of the manufacturer. Sabouraud dextrose agar (BioMérieux CZ) and Mueller-Hinton agar with 2\% glucose (LabMediaServis, Czechia) were culture media for disk test in the period of 1995 to 2005 and 2006 to 2017, respectively (CLSI, 2009). The latter agar was also used in the Etest. Since 2016 the paper disks in agar diffusion method has been replaced with tablets (Neo-Sensitabs, Rosco Diagnostica), but this modification of methodology concerned only two of $55 \mathrm{~S}$. clavata isolates tested. All strains were included in the statistical analysis according to the following criteria: one isolate (of the same species) per material and per one patient. Quality control strains of Candida albicans ATCC 90028, Candida krusei ATCC 6258 and Candida parapsilosis ATCC 22019 were included.

\section{Epidemiological Investigation}

The incidence of $S$. clavata strains at the University Hospital Hradec Králové during the period of 1995-2017 was retrospectively evaluated based on the recordings of the laboratory information system and the criteria mentioned above. Blood, cerebrospinal fluid, BAL fluid, sputum,

\footnotetext{
${ }^{1}$ http://blast.ncbi.nlm.nih.gov/Blast.cgi
} 


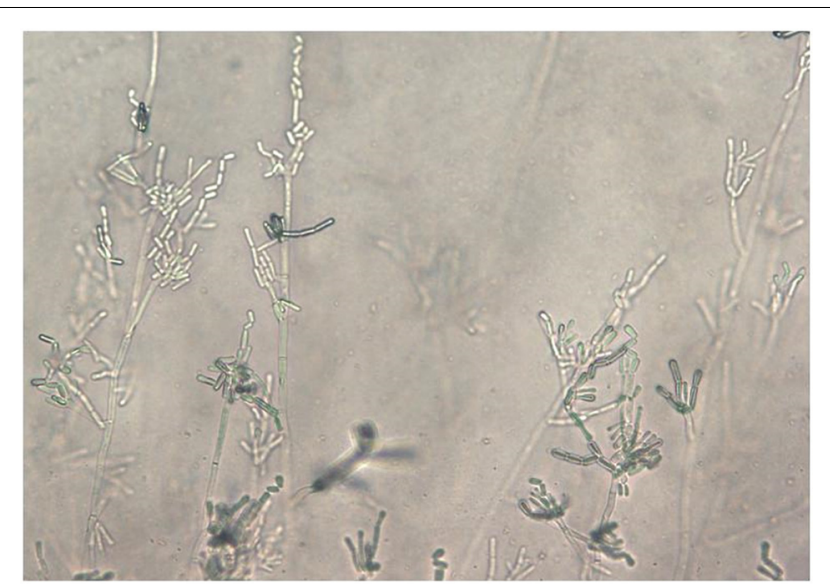

FIGURE 1 | Saprochaete clavata arthroconidia on Corn-Meal agar after 5 days at $35^{\circ} \mathrm{C}$ (slide culture; magn. $\times 40$ ).

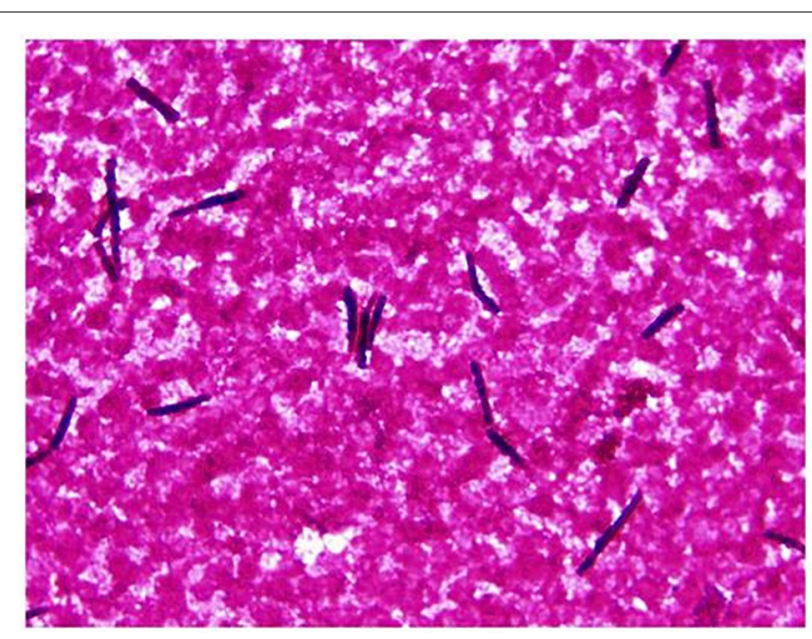

FIGURE 2 | Saprochaete clavata in blood culture. Arthroconidia-like hyphal fragments (Gram staining, magn. ×1000).

tracheal aspirate, urine, and other clinical specimens were microbiologically investigated.

\section{Cases}

Six patients were diagnosed with an infection due to S. clavata in the hematologic intensive care unit at our University Hospital between 2005 and 2017 (Table 1). The median age was 50.5 years (range 45 to 66 years), five patients $(83.3 \%)$ were female. Five patients were treated for acute myeloid leukemia (AML) and one for diffuse large B-cell lymphoma (DLBCL). The S. clavata infection in all patients was diagnosed based on a positive blood culture (Figure 2). In all patients, their management was complicated by bacterial opportunistic infections and by intensive therapy with broad-spectrum antibiotics and anticancer drugs including cytarabine. Five patients developed septic shock and required the use of artificial ventilation and/or hemodialysis. Histological investigation of necroptic samples demonstrated angioinvasivity of vessels with the tendency to disseminate to various organs, including the peritoneum, liver or spinal cord. Methenamine silver staining showed septate hyphae branching in acute angles unrecognizable from Aspergillus mycelium (Figures 3, 4). Four patients died of septic complications due to fungal and bacterial infections and concomitant hematologic disease. Two patients survived, but one died from an early relapse of AML later. Only one patient (no. 3) experienced a complete remission of AML. The relevant aspects of the treatment of individual patients are summarized in Table 1.

\section{Patient 1}

The male patient was diagnosed with AML 8 years after completing the treatment for Hodgkin lymphoma. The treatment of AML consisted of chemotherapy and allogeneic hematopoietic stem cell transplantation (HSCT), which was performed during complete remission. The patient's condition was complicated by a biliary obstruction of unknown etiology and required external biliary drainage. The first relapse of AML occurred after 4 years. The second remission of AML was not achieved after induction chemotherapy. The patient developed fever 20 days after chemotherapy (FLAG-Ida). S. clavata was cultured from blood. The patient developed septic shock and died of multiple organ dysfunction syndrome (MODS) 43 days after diagnosing $S$. clavata.

\section{Patient 2}

The female patient previously underwent resection for ovarian cancer. AML was diagnosed 3 years after the completion of the cancer treatment. A complete remission of AML was induced only after a second course of induction chemotherapy. A blood culture was positive for S. clavata. During a prolonged pancytopenia (absolute neutrophil count below 100/ml lasted 45 days) septic shock and MODS developed 8 days after diagnosing $S$. clavata. After the completion of treatment irreversible brain damage resulted. Subsequently, the active treatment of AML was terminated and the patient died 3 months after the diagnosis of AML.

\section{Patient 3}

The female patient previously underwent surgical treatment for cholecystitis. Six years later, she was diagnosed with AML. A complete remission was induced with the first course of induction therapy. S. clavata infection occurred after a first course of consolidation chemotherapy with high-dose cytarabine. This is the only patient who did not develop a septic shock and recovered hematopoietic function. She is still alive and remains in complete remission 87 months after allogeneic HSCT.

\section{Patient 4}

The female patient previously underwent resection for renal cell carcinoma as well as a resection and radiotherapy for colorectal carcinoma. She continued to suffer from a chronic anal fistula and a recurring Clostridium infection. Three years after undergoing radiotherapy patient was diagnosed with myelodysplastic syndrome (MDS) which developed into AML. The leukemia was treated with chemotherapy and allogeneic HSCT (alloHSCT) using a reduced-intensity regimen. Three 


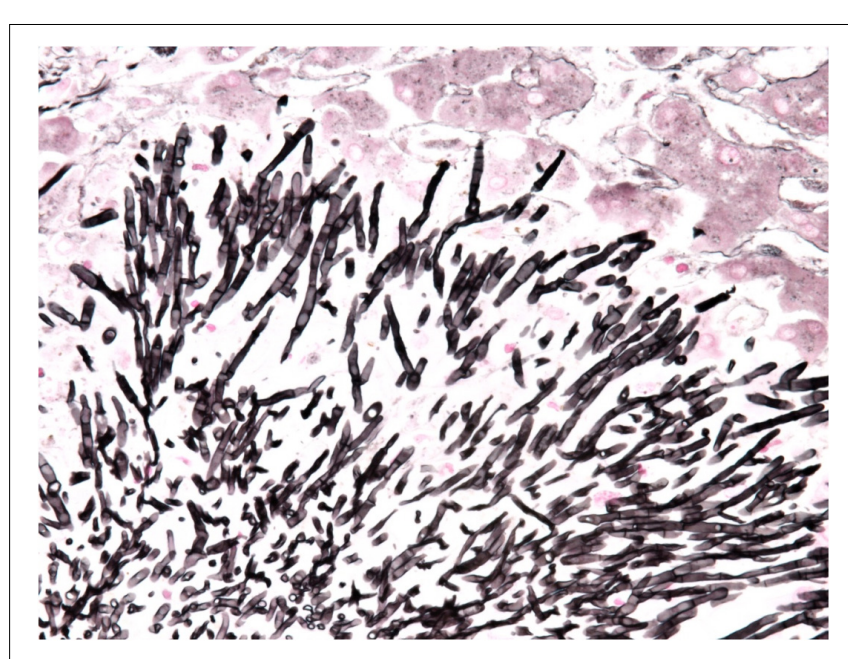

FIGURE 3 | Detail of microcolony of Saprochaete clavata invading liver by septated hyphae branching in acute angle (methenamine silver stain, magn. $\times 400)$

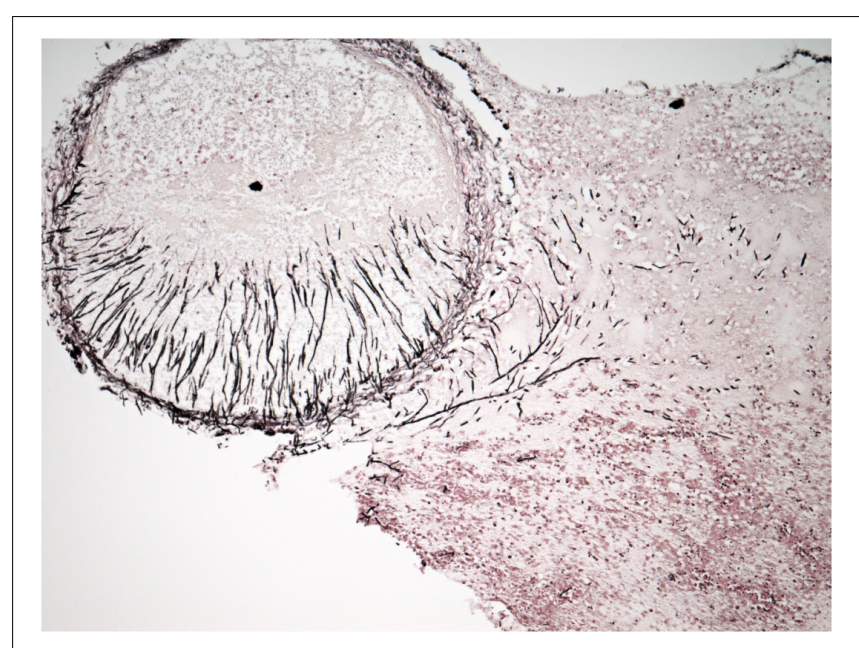

FIGURE 4 | Angioinvasion of spinal cord with hyphae (methenamine silver stain, magn. $\times 100)$.

months after alloHSCT acute graft-versus-host disease (GvHD) affected the skin and later on the intestine as well. The GvHD resolved after adding corticosteroid therapy. At the same time, she presented the first early relapse of AML and a new course of induction therapy (FLAG-Ida) was performed. The patient achieved incomplete remission of AML. The following month she was admitted for gastrointestinal bleeding and paralytic ileus. Due to histological confirmation of acute intestinal GvHD, the patient received corticosteroids in addition to standard supportive therapy. The general condition of the patient was very good and without gastrointestinal GvHD manifestation. Later, after the second alloHSCT, S. clavata was isolated from blood and stool. The course of treatment was complicated with septic shock and MODS 7 days after diagnosis S. clavata, which ultimately led to death.

\section{Patient 5}

The patient was treated for AML with chemotherapy and autologous peripheral blood stem cell transplantation. Three years later, the patient had a relapse of AML. Group B streptococci and C. albicans were cultivated from the nasopharyngeal swab. During a period of deep neutropenia, blood culture was positive for $S$. clavata. Eventually she developed septic shock with MODS and that resulted in death.

\section{Patient 6}

The female patient was treated for DLBCL. Due to infiltration and subsequent external biliary obstruction with a lymphoma, external drainage had to be performed. Following a course of R-CHOP chemotherapy, she developed combined hemorrhagic and septic shock with MODS. After the patient was stabilized, a surgical review identified the origin of the hepatic bleeding and liver packing was provided. Another septic shock occurred 2 weeks after candidemia caused by C. glabrata, when blood cultures became positive for S. clavata. Afterward, septic shock and MODS developed and the patient died.

\section{RESULTS}

Overall, 116 strains of $S$. clavata from 54 patients were obtained during the follow-up period. Almost all patients $(n=50,92.6 \%)$ were colonized with the species, only six (11.1\%) developed an infection with positive blood culture of which four had no other S. clavata findings and two were colonized - one before (biliary drainage fluid) and one after (rectal swab) fungemia. S. clavata was first identified in our institution in 2002 and was outnumbered by other arthroconidial species, especially T. asahii and $M$. capitatus, every year during the study period; only in 2007 it represented the most numerous species among these fungi (Figure 5). In contrast to other arthroconidial yeasts, female patients were more often colonized with $S$. clavata than males (55.6 vs. $44.4 \%$ ). The distribution of culture positive findings suggested three main sources of $S$. clavata in the human body: respiratory tract and to a lesser extent, the urogenital tract and the gastrointestinal tract (Figure 6). These sources partially overlapped with colonization potential that can be expressed as repeated isolations from the same material. They are tracheal aspirate, urine samples, and punctate fluid, in which the number of isolates per material was more than doubled compared to other materials with usually one isolate per specimen (Figure 6). The exception was blood where four of six patients had repeated positive blood samples for S. clavata. In addition, S. clavata was the most common species among the arthroconidial yeasts isolated from the blood $(6 \times S$. clavata, $3 \times M$. capitatus, and $2 \times T$. asahii) but there was no previous colonization of any catheter.

Prevalence of $S$. clavata in ICU patients was similar to those from standard departments $(50.8 \%$ in ICU vs. $49.2 \%$ in non-ICU), but all fungemic patients were hospitalized at the oncological-hematological department. Most of S. clavata isolates came from the patients of this clinic (29.1\%), followed 


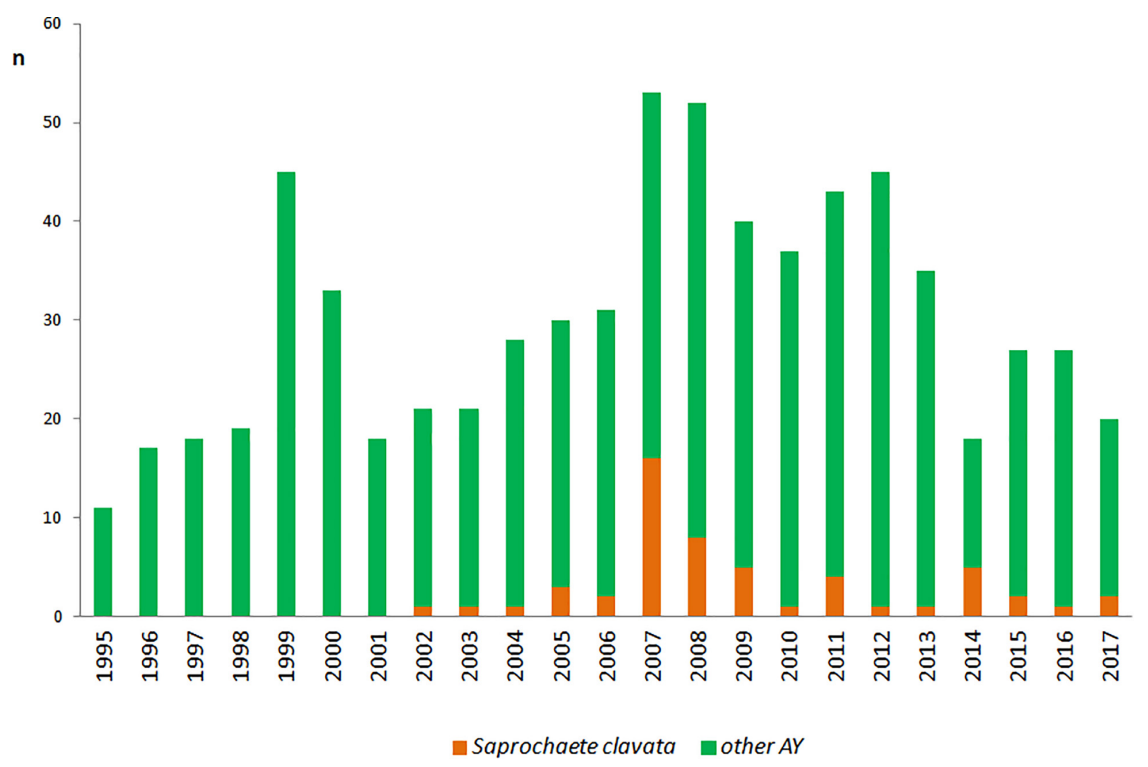

FIGURE 5 | Incidence of Saprochaete clavata and arthroconidial fungi at the University Hospital Hradec Kralové. n - number of isolates (one isolate of a given species per one patient). Other AY - number of isolates of arthroconidial yeasts (Galactomyces candidus, Magnusiomyces capitatus, Trichosporon asahii) without Saprochaete clavata.

by pulmonary $(21.8 \%)$ and geriatric-metabolic department (14.6\%) (Figure 7).

Antifungal susceptibility testing was affected by the method used during study period as the individual methods changed (Tables 2, 3). In sum, 13 strains were tested for MICs (Etest, Sensititre YeastOne) and 73 strains for inhibition zones (agar diffusion test). Based on the criteria (see section "Materials and Methods"), 12 and 55 of the strains were included in the analysis, respectively (Tables 2, 3). In general, Etest provided higher MICs than broth dilution format (Sensititre YeastOne). Our S. clavata strains displayed relatively low MICs against amphotericin B, voriconazole, itraconazole, flucytosine, and partly posaconazole, while the MICs of fluconazole and echinocandins were high (Table 2). The results of the disk test varied greatly. For voriconazole, posaconazole, flucytosine and echinocandins MICs corresponded well with the results from the disk test (Tables 2, 3).

Review of the literature and FungiScope ${ }^{\circledR}$ register revealed 73 cases of $S$. clavata infections in 10 countries most of which located in the Mediterranean (for details see Table 4). Only ten patients were from other regions - Germany, Serbia, China, and Czechia. The vast majority of patients manifested similar clinical signs and symptoms (neutropenia, fever, positivity of blood culture, dissemination and sepsis or septic shock, diarrhea) at time of diagnosis of S. clavata infection. The same was true for underlying conditions, including central venous catheter (CVC), broad-spectrum antibiotic therapy, aggressive chemotherapeutic regimens with cytarabine, and, in case of the French cohort, bacterial digestive decontamination (Vaux et al., 2014). Most patients were treated with voriconazole and/or lipidbased amphotericin $\mathrm{B}$, but mortality rate was extremely high (>65\%) (Table 4). In vitro and in vivo results confirmed that S. clavata is intrinsically resistant to echinocandins (Table 2).

\section{DISCUSSION}

Saprochaete clavata together with the Galactomyces, Magnusiomyces, and Trichosporon species represent rare human pathogenic fungi of heterogeneous origin, which share production of arthroconidia. S. clavata is almost exclusively confined to systemic, life-threatening infections while the clinical presentation of infections caused by other arthroconidial fungi range from superficial (Trichosporon spp.), mucosal (Galactomyces candidus), allergic (Trichosporon pneumonitis) to systemic forms ( $T$. asahii, M. capitatus, and G. candidus) (Girmenia et al., 2005; Henrich et al., 2009; Bonifaz et al., 2010; Vaux et al., 2014; de Almeida Júnior and Hennequin, 2016; Durán Graeff et al., 2017; Esposto et al., 2018; Leoni et al., 2018; Salgüero Fernández et al., 2018). AML is the leading underlying condition for systemic infections caused by $S$. clavata such as for other arthroconidial yeasts (Girmenia et al., 2005; Henrich et al., 2009; Camus et al., 2014; de Almeida Júnior and Hennequin, 2016).

All epidemiological aspects associated with $S$. clavata are not fully understood. Numbers of isolates of arthroconidial fungi obtained in our hospital during the period of 1995 to 2017 showed a noticeable fluctuation, which corresponded with similar course of fungemia outbreak in the French hospitals (Figure 3 in Vaux et al., 2014). That can suggest influence of some unknown epidemiological factor(s). All arthroconidial fungi are ubiquitous in nature but Trichosporon infections are more frequently described in the United States, while M. capitatus prevails in the Mediterranean area (Italy, France, Spain, Turkey, Greece, Tunisia, Israel, Libya, FungiScope ${ }^{\circledR}$ ) (Schiemann et al., 1998; Gadea et al., 2004; Christakis et al., 2005; Girmenia et al., 2005; García-Ruiz et al., 2013; Vaux et al., 2014; Trabelsi et al., 2015; 


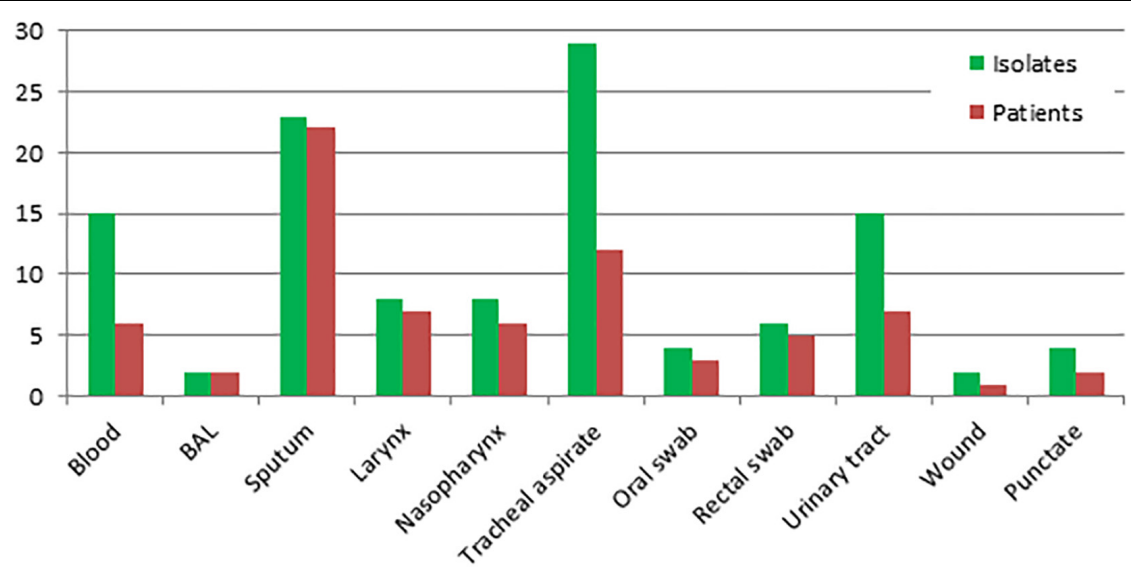

FIGURE 6 | Distribution of Saprochaete clavata by clinical material at the University Hospital Hradec Kralové in 1995-2017. Isolates - number of S. clavata isolates (including repeated ones per material and per one patient). Patients - number of $S$. clavata strains per patient without repeated isolates from the same material. $\mathrm{BAL}$ - bronchoalveolar lavage fluid, TAS - tracheal aspirate.

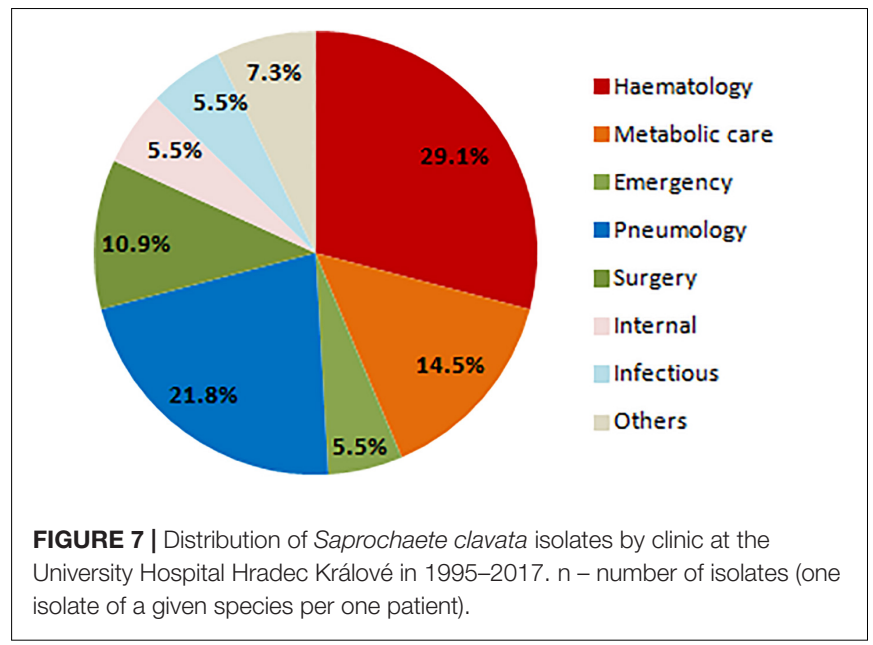

Del Principe et al., 2016; Durán Graeff et al., 2017; Esposto et al., 2018; Leoni et al., 2018; Salgüero Fernández et al., 2018). We found no correlation between temperature in the Czechia and in Eastern Bohemia and the number of isolated S. clavata strains during the follow-up period (data not shown).

As regards potential sources of these fungi, main suspicion falls on in-house environment (dishwasher) and food, especially milk and dairy products (Bouakline et al., 2000; Gurgui et al., 2011; Zalar et al., 2011; Vaux et al., 2014; Banjara et al., 2015; Gouba and Drancourt, 2015). It is worth mentioning interpersonal transmission among hospitalized patients as reported during the French outbreak and the potential of fly-to-human transmission as suggested by the positive $S$. clavata isolates from Drosophila flies (Pimenta et al., 2009; Vaux et al., 2014). In line with the reports on other arthroconidial fungi, the respiratory tract seems to be the main ecological niche colonized by $S$. clavata in debilitated patients, whereas the intestine and/or urogenital tract may be less relevant (Figure 6). Metagenomic studies have not revealed $S$. clavata in human microbiota in contrast to the species of Galactomyces and Trichosporon, which are part of the gut microbiome and together with Candida, Malassezia, and sporulating molds constitute core gut mycobiota (Gouba et al., 2014; Hallen-Adams and Suhr, 2017; Auchtung et al., 2018; Li et al., 2018).

To date, little is known about the virulence mechanisms of S. clavata. There is no data about biofilm production of S. clavata, only indirect suggestions based on a close relation between the presence of CVC and a positive blood culture (this study, Girmenia et al., 2005; Camus et al., 2014; Picard et al., 2014; Vaux et al., 2014; Del Principe et al., 2016). Compared to T. asahii, S. clavata is more genetically monomorphic (Sun et al., 2012; Vaux et al., 2014). Two main clades (A and B) of S. clavata were identified during the French outbreak (Vaux et al., 2014). The clinical significance of both clades was similar in most characteristics, including their susceptibility to antifungal drugs. Although clade A exhibited lower virulence expressed by longer survival of experimentally infected mice, it was responsible for most cases of the French outbreak (Vaux et al., 2014). That indicates higher human-to-human transmissibility of the clade A or its better adaptability to unknown environment (source), which can be responsible for an increased exposure of vulnerable patients to this clade (Vaux et al., 2014).

Clinically, S. clavata infections are difficult to distinguish from $M$. capitatus infections and the majority of other invasive mycoses. No reliable diagnostic tests are available and thus, in the absence of any specific signs and symptoms, positive blood cultivation remains indicative for this mycosis. It is difficult to establish an early diagnosis, which increases the likelihood for the optimal timing of antifungal treatment before the development of advanced and more difficult-to-control stage of the infection. There is no surprise that the mortality rate was extremely high and reached $66.6 \%$ in our patients; that was comparable to overall mortality of other reported cases (Table 4). In this way, blood culture positivity seems to represent not only diagnostic but also a poor prognostic factor. 
TABLE 2 | Review of in vitro susceptibility of Saprochaete clavata isolates to antifungal drugs.

\begin{tabular}{|c|c|c|c|c|c|c|c|c|c|c|c|c|}
\hline Specimen (n) & $\begin{array}{l}\text { Drug } \\
\text { Methods* }\end{array}$ & $\begin{array}{c}\text { AMB } \\
\begin{array}{c}\text { GM } \\
\text { Range }\end{array}\end{array}$ & 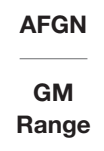 & $\frac{\text { MFGN }}{\underset{\text { GM }}{\text { Range }}}$ & $\frac{\text { CFGN }}{\underset{\text { GM }}{\text { Range }}}$ & $\begin{array}{c}\text { PSZ } \\
\begin{array}{c}\text { GM } \\
\text { Range }\end{array}\end{array}$ & $\begin{array}{c}\text { VRZ } \\
\begin{array}{c}\text { GM } \\
\text { Range }\end{array}\end{array}$ & $\frac{\text { ITZ }}{\underset{\text { RM }}{\text { Range }}}$ & $\frac{\text { FLZ }}{\underset{\text { GM }}{\text { Range }}}$ & $\begin{array}{c}\text { ISZ } \\
\begin{array}{c}\text { GM } \\
\text { Range }\end{array}\end{array}$ & $\begin{array}{c}5 \mathrm{FC} \\
\begin{array}{c}\mathrm{GM} \\
\text { Range }\end{array}\end{array}$ & Source \\
\hline Blood (7) & Etest & 0.955 & 32 & 3 & 36.6 & 9.97 & 0.676 & 0.794 & 18.4 & & & This study \\
\hline Sputum (2) & $\mathrm{n}^{\#}$ & $0.25-2$ & 32 & 3 & $32-48$ & $2-32$ & $0.094-8$ & $0.25-4$ & $4-128$ & & & \\
\hline \multirow[t]{2}{*}{ Others $^{\S}(4)$} & YeastOne & 0.574 & 1.74 & 2 & 8 & 0.285 & 0.058 & 0.092 & 6.96 & & 0.091 & \\
\hline & $n=5$ & $0.5-1$ & $1-2$ & $1-4$ & $2-16$ & $0.12-0.5$ & $0.015-0.5$ & $0.03-0.25$ & $2-32$ & & $0.06-0.12$ & \\
\hline \multirow[t]{2}{*}{ Clinical isolates (4) } & CLSI & & & 2.25 & & 4 & 0.19 & & & 0.88 & & Pfaller et al., 2015 \\
\hline & M27-A3 & & & $1-4$ & & 4 & $0.062-0.5$ & & & $0.5-2$ & & \\
\hline Human/ & CLSI & 0.22 & 2 & 6.7 & & 0.25 & 0.25 & 0.27 & 19 & 0.54 & & Kaplan et al., 2017 \\
\hline Dishwasher (8) & M27-A3 & $0.125-0.5$ & 2 & $2-8$ & & 0.25 & $0.063-0.5$ & $0.25-0.5$ & $16-32$ & $0.125-1$ & & \\
\hline Blood (3) & Etest & $1-1.5$ & $>32$ & $>32$ & $>32$ & $0.19-0.5$ & $0.094-0.125$ & & & & & Picard et al., 2014 \\
\hline \multirow[t]{2}{*}{ Blood (3) } & YeastOne & 0.42 & 1 & 0.5 & 8 & 0.17 & 0.05 & 0.09 & 2.67 & & & Del Principe et al., 2016 \\
\hline & Sensititre & $0.25-0.5$ & 1 & 0.5 & 8 & $0.125-0.25$ & $0.03-0.06$ & $0.03-0.12$ & $2-4$ & & & \\
\hline \multirow[t]{2}{*}{ Blood (45) } & EUCAST & 0.5 & & & 8 & 0.5 & 1 & & & & 0.25 & Vaux et al., 2014 \\
\hline & E.Def 7.2 & $0.125-1$ & & & $1-8$ & $0.125-1$ & $0.06-2$ & & & & $<0.125-1$ & \\
\hline Blood (1) & Etest & 1 & & & & 0.75 & 0.064 & & 12 & & & Camus et al., 2014 \\
\hline \multirow[t]{2}{*}{ Blood (1) } & EUCAST & 0.25 & & $>4$ & $>4$ & 0.5 & 0.5 & & 32 & & 0.25 & Favre et al., 2016 \\
\hline & E.Def 9.1 & & & & & & & & & & & \\
\hline \multirow[t]{2}{*}{ Clinical isolates (4) } & Etest & 1.25 & 3 & 0.56 & $>32$ & 0.16 & 0.13 & 0.13 & 20.3 & 0.014 & 16.1 & Durán Graeff et al., 2017 \\
\hline & & $1-2$ & $2-4$ & $0.25-1$ & $>32$ & $0.032-0.25$ & $0.016-0.25$ & $0.002-0.25$ & $1-32$ & $0.004-0.25$ & $0.06->32$ & \\
\hline Blood (1) & MIC test & $\leq 0.5$ & & & & & 0.125 & $\leq 0.125$ & 2 & & $\leq 4$ & Liu et al., 2018 \\
\hline \multirow[t]{2}{*}{ Blood (18) } & YeastOne & 0.96 & & & & 0.56 & 0.34 & 0.31 & 17.96 & 0.71 & 0.18 & Esposto et al., 2018 \\
\hline & Sensititre & $0.5-1$ & & & & $0.25-1$ & $0.03-1$ & $0.12-0.5$ & $8-64$ & $0.12-4$ & $0.06-0.5$ & \\
\hline \multirow[t]{2}{*}{ Blood (1) } & YeastOne & 0.25 & $\mathrm{R}$ & $\mathrm{R}$ & $\mathrm{R}$ & 0.25 & 0.5 & & 32 & & 0.12 & Salgüero Fernández et al., 2018 \\
\hline & Sensititre & & & & & & & & & & & \\
\hline
\end{tabular}

*Quantitative test (MIC, mg/ml); GM - geometric mean; $n$ - number of isolates. \#The number of strains tested with Etest in brackets, AMB (7), VRZ (6), FLZ (5), PSZ (5), ITZ (3), CFGN (3), AFGN (1), MFGN (1). §Laryngeal swab, punctate, urine, drainage fluid. R-interpreted as resistant according to EUCAST standard (document not specified), AMB - amphotericin B, $5 F C$ - flucytosine, AFGN - anidulafungin, MFGN - micafungin, CFGN caspofungin, PSZ - posaconazole, VRZ - voriconazole, ITZ - itraconazole, FLZ - fluconazole, ISZ - isavuconazole. 
Apart from blood culture, antigen detection can be useful in diagnosis of arthroconidial fungi because they share a cross-reactivity with cryptococcal glucuronoxylomannan (T. asahii, M. capitatus), Aspergillus galactomannan (G. candidus, M. capitatus), and $\beta$-D-glucan (Odabasi et al., 2006; Bonini et al., 2008; Liao et al., 2012a; Nakase et al., 2012; Trabelsi et al., 2015; de Almeida Júnior and Hennequin, 2016; Del Principe et al., 2016). In our patients, three out of five (the sixth not tested) had galactomannan index values from 0.5 to 0.7 (the other two $\leq 0.3$ ) at the time of diagnosis of $S$. clavata fungemia (Table 4). Available data from other studies showed a lower sensitivity of the galactomannan test and questioned its practical use (Picard et al., 2014; Del Principe et al., 2016). In an Italian study, positive $\beta-\mathrm{D}$-glucan test results were documented in two out of three patients (Del Principe et al., 2016). To date, the experience with the methods in S. clavata infection is little but promising results support further investigation of their clinical usefulness.

Culture-dependent identification of Galactomyces, Saprochaete, and Trichosporon is limited to AuxaColor (BioRad), API ID32C (BioMérieux) or VITEK 2 system (ID-YST card; BioMérieux). Unfortunately, none of the systems covers $S$. clavata. In general, the accuracy of identification of arthroconidial yeasts by these methods is not reliable (Posteraro et al., 2015). The use of phenotypic tests may be a source of misidentification, especially when cellobiose assimilation is missing (Smith and Poot, 1998; Desnos-Ollivier et al., 2014). Desnos-Ollivier et al. (2014) described about $15 \%$ of S. clavata strains that did not assimilate cellobiose. Hence, such "cellobiosenegative $M$. capitatus" strains may have escaped our attention in the past. Recently, the MALDI-TOF mass spectrometry (Biotyper 3.0) has displayed the most promising laboratory tool for determination of and discrimination between arthroconidial fungi, including S. clavata, even though reliability varies (Seyfarth et al., 2012; Kolecka et al., 2013). ITS, $18 \mathrm{~S}$ rRNA or proteincoding loci (e.g., $R b p 2$ ) sequencing may be a reasonable approach to confirm results of other methods (this study, Desnos-Ollivier et al., 2014; Durán Graeff et al., 2017; Kaplan et al., 2017).

The role of antifungal susceptibility testing in the management of infections caused by arthroconidial fungi

TABLE 3 | Antifungal susceptibility of Saprochaete clavata isolates* by disk diffusion method at the University Hospital, Hradec Králové in the period of 1995-2017.

\begin{tabular}{lcccccccc}
\hline & AMB & FLZ & ITZ & VRZ & PSZ & KTZ & CFGN & 5FC \\
\hline $\mathrm{n}$ & 60 & 69 & 68 & 53 & 5 & 16 & 5 & 7 \\
$\mathrm{GM}$ & 12.6 & 15.9 & 14.8 & 20.2 & 18.4 & 23.6 & 8.8 & 35.0 \\
range & $8-25$ & $6-32$ & $9-29$ & $6-33$ & $14-22$ & $18-28$ & $6-12$ & $22-51$ \\
IZ50 & 13 & 18 & 14 & 20 & 19 & 25 & 9 & 35 \\
IZ90 & 9.5 & 6 & 11 & 15 & & 19 & & \\
\hline
\end{tabular}

* Only isolates that met the following criteria were included in the statistical analysis: one isolate/species per one material and per one patient. GM - geometric mean (inhibition zone in $\mathrm{mm}$ ), $n$ - number of strains, IZ50/IZ90 - lower limit of inhibition zone $(\mathrm{mm})$ encompassing $50 \% / 90 \%$ of isolates tested. AMB - amphotericin B, FLZ - fluconazole, ITZ - itraconazole, VRZ - voriconazole, PSZ - posaconazole, CFGN - caspofungin, 5FC - flucytosine, KTZ - ketoconazole. is controversial because of lack of standardized methods. Our MICs were influenced by changing methodologies during the follow-up period $\left(\right.$ Etest $^{\circledR}$, YeastOne ${ }^{\mathrm{TM}}$ ), but most of them were in line with the results of other studies (Tables 2, 3). The inhibition zones corresponded well with the MICs in case of fluconazole, voriconazole, posaconazole, flucytosine, and echinocandins and disk test may serve as a tentative method for surveillance of $S$. clavata isolates. As no breakpoints and epidemiological cut-off are defined for S. clavata yet, interpretation of the susceptibility test results should be done with caution. One has to take into account the clinical form and course of the infection, the pharmacological profile of a given drug or drug formulation, and the presence of risk and predisposing factors in a patient (Arendrup et al., 2014).

Invasive infections caused by arthroconidial fungi typically manifest as fungemia with a tendency to disseminate in immunocompromised patients. They are characterized by a relatively high blood recovery rate and the involvement of different visceral organs such as the lungs, spleen and liver (Girmenia et al., 2005; Vaux et al., 2014; Cornely et al., 2015; Durán Graeff et al., 2017). Our S. clavata patients displayed no pulmonary symptoms, even when one patient (No. 5) was positive for bioptic sample of lungs (Table 1). This is in contrast to frequently reported findings in more than half of the French outbreak patients (Vaux et al., 2014). On the other hand, two thirds of our patients have experienced cholelithiasis or cholecystitis, which has been mentioned previously in only one female patient with S. clavata infection (Del Principe et al., 2016). That could be due to a relative lack of primary bile salts as a result of gallstone formation and their lower availability for the intestinal microbiota, which converts them to secondary salts with antimicrobial effect on some bacteria and also on C. albicans (Guinan et al., 2018; Kelly et al., 2019). Alternatively, it may be the result of antibiotic therapy or cholecystectomy that can alter composition of transformation microbiota and indirectly interfere with the production of secondary salt (Theriot et al., 2016; Wang et al., 2018). Microbiota connection is supported with the digestive tract decontamination (gentamicin and/or colistin) to which more than half of French patients have been exposed and suffered from diarrhea (Vaux et al., 2014). Another risk factor in S. clavata infection is anticancer drug cytosine arabinoside (cytarabine) (Stentoft, 1990; Camus et al., 2014; Picard et al., 2014; Vaux et al., 2014; Del Principe et al., 2016) with specific effect on the neutrophil count and mucosal integrity. Preferential use of more aggressive regimens of cytarabine $\left(\geq 2000 \mathrm{mg} / \mathrm{m}^{2}\right.$ twice daily) in recent years could contribute to $S$. clavata infection, like in case of five of our patients (Willemze et al., 2014).

A relatively high MIC of fluconazole $(\geq 4 \mathrm{mg} / \mathrm{l})$ in strains isolated from our patients suggested that the prophylactic treatment with the triazole drug could represent a selective pressure for $S$. clavata overgrowth. That is supported with the reports on development of breakthrough infections caused by arthroconidial yeasts in immunocompromised patients on fluconazole or echinocandin prophylaxis or empirical regimen 
TABLE 4 | Summary of case characteristics of Saprochaete clavata infections from literature and FungiScope ${ }^{\circledR}$.

\begin{tabular}{|c|c|c|c|c|c|c|c|c|c|c|c|c|}
\hline Study & Country & Sex & Age & $\begin{array}{l}\text { Underlying } \\
\text { disease }\end{array}$ & Risk factor" & Clinical form & $\begin{array}{l}\text { Positive } \\
\text { specimen }\end{array}$ & Lab diagnosis & Drug & Dosage & Duration & Outcome \\
\hline \multirow{8}{*}{$\begin{array}{l}\text { Lacroix } \\
\text { et al., } 2007\end{array}$} & \multirow[t]{8}{*}{ France } & \multirow[t]{3}{*}{ M } & \multirow[t]{3}{*}{14} & \multirow[t]{3}{*}{ AML } & \multirow[t]{3}{*}{ CVC, cytarabine } & \multirow[t]{3}{*}{ Sepsis } & \multirow[t]{3}{*}{ Blood } & \multirow[t]{3}{*}{ Blood culture } & $\mathrm{E}: \mathrm{AMB}$ & \multirow[t]{3}{*}{ ns } & 1 day & \multirow[t]{3}{*}{ Survived } \\
\hline & & & & & & & & & T: L-AMB + VRZ & & 5 days & \\
\hline & & & & & & & & & $\mathrm{T}: \mathrm{VRZ}+5 \mathrm{FC}$ & & ns & \\
\hline & & \multirow[t]{5}{*}{ M } & \multirow[t]{5}{*}{59} & \multirow[t]{5}{*}{ AML } & \multirow[t]{5}{*}{ CVC, cytarabine } & \multirow[t]{5}{*}{$\mathrm{BSI}$} & \multirow{5}{*}{$\begin{array}{l}\text { Blood, urine, } \\
\text { biopsy (skin) }\end{array}$} & \multirow{5}{*}{$\begin{array}{l}\text { Blood culture, } \\
\text { GM negative }\end{array}$} & P: CFGN & ns & 7 days & \multirow[t]{5}{*}{ Survived } \\
\hline & & & & & & & & & $E: C F G N+L-A M B$ & $3 \mathrm{mg} / \mathrm{kg} / \mathrm{d}$ (L-AMB) & 7 days & \\
\hline & & & & & & & & & E: L-AMB + PSZ & & 4 days & \\
\hline & & & & & & & & & T: L-AMB + 5FC + PSZ & $5 \mathrm{mg} / \mathrm{kg} / \mathrm{d}(\mathrm{L}-\mathrm{AMB})$ & 7 days & \\
\hline & & & & & & & & & T: L-AMB + 5FC + VRZ & & 21 days & \\
\hline \multirow[t]{3}{*}{$\begin{array}{l}\text { Picard } \\
\text { et al., } 2014\end{array}$} & \multirow[t]{3}{*}{ France } & $\mathrm{F}$ & 46 & AML & $\begin{array}{l}\text { CVC, cytarabine, } \\
\text { digestive } \\
\text { decontamination } \\
\text { (GEN, COL), } \\
\text { PIP,AMI,VAN,CIP }\end{array}$ & $\begin{array}{l}\text { BSI, } \\
\text { disseminated }\end{array}$ & Blood, stool, TAS & $\begin{array}{l}\text { Blood culture, } \\
\text { GM positive }\end{array}$ & $\begin{array}{l}\text { P: PSZ } \\
\text { T: L-AMB + VRZ } \\
\text { E: CFGN }\end{array}$ & ns & 24 days & Died \\
\hline & & M & 70 & AML & $\begin{array}{l}\text { CVC, digestive } \\
\text { decontamination } \\
\text { (GEN, COL), } \\
\text { PIP,AMI,VAN,CIP }\end{array}$ & BSI, pulmonary & Blood & Blood culture, & E: CFGN & ns & 4 days & Died \\
\hline & & $\mathrm{F}$ & 63 & AML & $\begin{array}{l}\text { CVC, digestive } \\
\text { decontamination } \\
\text { (GEN, COL), } \\
\text { PIP,AMI,VAN,CIP }\end{array}$ & $\begin{array}{l}\mathrm{BSI}, \\
\text { disseminated }\end{array}$ & Blood, stool, TAS & Blood culture & $\begin{array}{l}\text { E: CFGN } \\
\text { T: L-AMB + VORI }\end{array}$ & ns & $\begin{array}{l}6 \text { days (CFGN) } \\
10 \text { days (L-AMB + VRZ) }\end{array}$ & Died \\
\hline \multirow[t]{3}{*}{$\begin{array}{l}\text { Del Principe } \\
\text { et al., } 2016\end{array}$} & \multirow[t]{3}{*}{ Italy } & $\mathrm{F}$ & 36 & AML & $\begin{array}{l}\text { CVC, cytarabine, } \\
\text { neutropenia, } \\
\text { PIP-Taz, MER }\end{array}$ & $\begin{array}{l}\text { Pulmonary, } \\
\text { cholecystitis, } \\
\text { hepatosplenic } \\
\text { abscesses }\end{array}$ & Blood, CVC & $\begin{array}{l}\text { Blood culture, } \\
\text { betaG > } 500 \\
\mathrm{pg} / \mathrm{ml}, \mathrm{GM} \\
\text { negative }\end{array}$ & $\begin{array}{l}\text { T: L-AMB } \\
\text { VRZ (after discharge) }\end{array}$ & $\begin{array}{l}350 \mathrm{mg} \text { qd iv } \\
200 \mathrm{mg} \text { bid oral }\end{array}$ & $\begin{array}{l}100 \text { days (L-AMB) } \\
15 \text { days (FungiScope) }\end{array}$ & Survived \\
\hline & & $\mathrm{F}$ & 50 & MC lymphoma & $\begin{array}{l}\text { CVC, cytarabine, } \\
\text { steroids, } \\
\text { neutropenia } \\
\left(<500 \mathrm{~mm}^{3}\right)\end{array}$ & $\begin{array}{l}\text { Pneumonia, } \\
\text { splenic } \\
\text { infiltrates, } \\
\text { sepsis }\end{array}$ & Blood & $\begin{array}{l}\text { Blood culture, } \\
\text { betaG }>500 \\
\mathrm{pg} / \mathrm{ml}, \mathrm{GM} \\
\text { negative }\end{array}$ & $\begin{array}{l}\text { T: L-AMB } \\
\text { VRZ (after discharge) }\end{array}$ & $\begin{array}{l}200 \mathrm{mg} \text { qd iv } \\
350 \mathrm{mg} \text { qd iv }\end{array}$ & $\begin{array}{l}10 \text { days ( }(\mathrm{L}-\mathrm{AMB}) \\
47 \text { days }(\mathrm{L}-\mathrm{AMB})\end{array}$ & Died \\
\hline & & M & 21 & AML & $\begin{array}{l}\text { Methyl- } \\
\text { prednisolone, } \\
\text { neutropenia } \\
\left(<500 \mathrm{~mm}^{3}\right) \text {, } \\
\text { PIP-Taz, MER, } \\
\text { cytarabine }\end{array}$ & $\begin{array}{l}\text { Splenic } \\
\text { abscesses }\end{array}$ & Blood, CVC & $\begin{array}{l}\text { Blood culture, } \\
\text { betaG negative, } \\
\text { GM negative }\end{array}$ & $\begin{array}{l}\text { T: L-AMB } \\
\text { VRZ (after discharge) }\end{array}$ & $\begin{array}{l}200 \mathrm{mg} \text { qd iv } \\
600 \mathrm{mg} \text { bid oral }\end{array}$ & $\begin{array}{l}12 \text { days (L-AMB) } \\
1 \text { day (NRZ) }\end{array}$ & Survived \\
\hline
\end{tabular}




\section{TABLE 4 | Continued}

\begin{tabular}{|c|c|c|c|c|c|c|c|c|c|c|c|c|}
\hline Study & Country & Sex & Age & $\begin{array}{l}\text { Underlying } \\
\text { disease }\end{array}$ & Risk factor" & Clinical form & $\begin{array}{l}\text { Positive } \\
\text { specimen }\end{array}$ & Lab diagnosis & Drug & Dosage & Duration & Outcome \\
\hline \multirow[t]{4}{*}{$\begin{array}{l}\text { Vaux et al., } \\
2014\end{array}$} & \multirow[t]{4}{*}{ France } & $F(15)^{\circledR}$ & 63 & AML (70\%) & $\begin{array}{l}\text { Neutropenia } \\
\left(<500 \mathrm{~mm}^{3} \text {; }\right. \\
90 \%) \text {, cytarabine } \\
(78.3 \%)\end{array}$ & BSI (87\%), & $\begin{array}{l}\text { Blood, stool, } \\
\text { BAL, }\end{array}$ & Blood culture & ns & ns & ns & $\begin{array}{l}24(80 \%) \\
\text { died }\end{array}$ \\
\hline & & \multirow[t]{3}{*}{$M(15)^{\oplus}$} & \multirow[t]{3}{*}{ (mean) } & ALL (20\%) & & $\begin{array}{l}\text { pulmonary } \\
(40 \%),\end{array}$ & TAS & (86.7\%) & & & & \multirow[t]{3}{*}{$\begin{array}{l}6(20 \%) \\
\text { survived }\end{array}$} \\
\hline & & & & CLM (3.3\%) & & $\begin{array}{l}\text { diarrhea } \\
(61.5 \%)\end{array}$ & & & & & & \\
\hline & & & & other (6.7\%) & & & & & & & & \\
\hline $\begin{array}{l}\text { Camus } \\
\text { et al., } 2014\end{array}$ & France & M & 32 & AML & $\begin{array}{l}\text { Cytarabine, IMI, } \\
\text { VAN, MET IMI, } \\
\text { VAN, MET }\end{array}$ & $\begin{array}{l}\text { Sepsis, } \\
\text { peritonitis, } \\
\text { Hepatic lesions }\end{array}$ & $\begin{array}{l}\text { Blood, stool, } \\
\text { ascites }\end{array}$ & $\begin{array}{l}\text { Blood culture, } \\
\text { GM negative }\end{array}$ & $\begin{array}{l}\text { E: CFGN } \\
\text { T: VRZ }\end{array}$ & $\begin{array}{l}50 \mathrm{mg} \text { qd iv } \\
300 \mathrm{mg} \text { qd iv } \\
100 \mathrm{mg} \text { qd iv }\end{array}$ & $\begin{array}{l}8 \text { days (CFGN) } \\
35 \text { days (VRZ iv) } \\
>270 \text { days (VRZ po) }\end{array}$ & Survived \\
\hline $\begin{array}{l}\text { Favre et al., } \\
2016\end{array}$ & France & M & 27 & Aplastic anemia & $\begin{array}{l}\text { CVC, } \\
\text { neutropenia, } \\
\text { prednisone, } \\
\text { PIP-Taz, AMI, } \\
\text { MER, LVX }\end{array}$ & $\begin{array}{l}\text { BSI, } \\
\text { disseminated }\end{array}$ & Blood, CVC & Blood culture & $\begin{array}{l}\text { E: CFGN } \\
\text { T: L-AMB + VRZ }\end{array}$ & $\begin{array}{l}50 \mathrm{mg} \text { qd iv } \\
200 \mathrm{mg} \text { bid iv } \\
\text { (L-AMB) } \\
400 \mathrm{mg} \text { bid iv (VRZ) }\end{array}$ & $\begin{array}{l}2 \text { days (CFGN) } \\
55 \text { days (L-AMB + VRZ) }\end{array}$ & Survived \\
\hline $\begin{array}{l}\text { de Almeida } \\
\text { Júnior } \\
\text { et al., } 2016\end{array}$ & Brazil & $\mathrm{F}$ & 6 & $\begin{array}{l}\text { Hemophagocytic } \\
\text { lymphohis- } \\
\text { tiocytosis }\end{array}$ & $\begin{array}{l}\text { Auto BMT, CVC, } \\
\text { neutropenia }\end{array}$ & & & & $\begin{array}{l}\text { T: AMB-D } \\
\text { T: VRZ }\end{array}$ & ns & 18 days & Died \\
\hline $\begin{array}{l}\text { Fungiscope } \\
\text { - } 831\end{array}$ & Turkey & $\mathrm{F}$ & 37 & AML (relapse) & $\begin{array}{l}\text { Neutropenia } \\
\left(<500 \mathrm{~mm}^{3}\right)\end{array}$ & $\mathrm{BSI}$ & Blood & Blood culture & T: VRZ & $\begin{array}{l}240 \mathrm{mg} \text { bid iv } \\
200 \mathrm{mg} \text { bid oral }\end{array}$ & $\begin{array}{l}8 \text { days } \\
6 \text { days }\end{array}$ & Survived \\
\hline $\begin{array}{l}\text { Fungiscope } \\
-1211\end{array}$ & Israel & $\mathrm{F}$ & 17 & AML & $\begin{array}{l}\text { Neutropenia } \\
\left(<500 \mathrm{~mm}^{3}\right)\end{array}$ & $\begin{array}{l}\text { Disseminated } \\
\text { (CNS, liver, } \\
\text { spleen) }\end{array}$ & & PCR (CSF) & $\begin{array}{l}\text { E: L-AMB } \\
\text { T: L-AMB } \\
\text { T: } 5 F C \\
\text { T: VRZ }\end{array}$ & $\begin{array}{l}250 \mathrm{mg} \text { qd iv } \\
250 \mathrm{mg} \text { qd iv } \\
1000 \mathrm{mg} 4 \mathrm{x} \text { oral } \\
200 \mathrm{mg} \text { bid iv }\end{array}$ & $\begin{array}{l}12 \text { days } \\
27 \text { days } L-A M B \text { then } 5 \\
\text { days } \\
\text { L-AMB }+5 F C \\
5 \text { days } L-A M B+5 F C \\
208 \text { days } L-A M B+5 F C+ \\
V R Z\end{array}$ & $\begin{array}{l}\text { Alive, } \\
\text { ongoing } \\
\text { therapy }\end{array}$ \\
\hline
\end{tabular}


TABLE 4 | Continued

\begin{tabular}{|c|c|c|c|c|c|c|c|c|c|c|c|c|}
\hline Study & Country & Sex & Age & $\begin{array}{l}\text { Underlying } \\
\text { disease }\end{array}$ & Risk factor $\#$ & Clinical form & $\begin{array}{l}\text { Positive } \\
\text { specimen }\end{array}$ & Lab diagnosis & Drug & Dosage & Duration & Outcome \\
\hline $\begin{array}{l}\text { Fungiscope } \\
-1216\end{array}$ & Spain & M & 48 & Lymphoma & $\begin{array}{l}\text { alloHSCT, } \\
\text { neutropenia } \\
\left(<500 \mathrm{~mm}^{3}\right)\end{array}$ & $\begin{array}{l}\text { BSI, } \\
\text { disseminated } \\
\text { (CNS, liver, } \\
\text { lung, spleen) }\end{array}$ & Blood & $\begin{array}{l}\text { Blood culture, } \\
\text { PCR (pleural fluid) }\end{array}$ & $\begin{array}{l}\text { E: L-AMB } \\
\text { E: VRZ } \\
\text { T: L-AMB } \\
\text { T: VRZ } \\
\text { T: 5FC } \\
2^{\text {nd }} P: \text { PSZ } \\
\text { T: L-AMB } \\
\text { T: 5FC }\end{array}$ & $\begin{array}{l}400 \mathrm{mg} \text { qd iv } \\
200 \mathrm{mg} \text { bid iv } \\
400 \mathrm{mg} \text { qd iv } \\
200 \mathrm{mg} \text { bid iv } \\
37.5 \mathrm{mg} 4 \mathrm{x} \text { iv } \\
300 \mathrm{mg} \text { qd tab } \\
400 \mathrm{mg} \text { qd iv } \\
37.5 \mathrm{mg} 4 \mathrm{x} \text { iv }\end{array}$ & $\begin{array}{l}3 \text { days ( } 2 \text { days with VRZ) } \\
2 \text { days (with } L-A M B \text { ) } \\
99 \text { ( } 11 \text { days with } V R Z \text {, } \\
\text { then } 31 \text { days with } 5 F C \text { ) } \\
11 \text { days (with } L-A M B \text { ) } \\
31 \text { days (with } L-A M B \text { ) } \\
92 \text { days (mono) } \\
9 \text { days (with } 5 F C \text { ) } \\
9 \text { days (with } L-A M B \text { ) }\end{array}$ & Died \\
\hline $\begin{array}{l}\text { Fungiscope } \\
\text { - } 604\end{array}$ & Germany & $M$ & 55 & AML (relapse) & $\begin{array}{l}\text { alloHSCT (PBSC), } \\
\text { neutropenia } \\
\left(<500 \mathrm{~mm}^{3}\right) \text {, ICU }\end{array}$ & & Blood & Blood culture & $\begin{array}{l}\text { E: L-AMB } \\
\text { T: VRZ }\end{array}$ & $\begin{array}{l}290 \mathrm{mg} \text { qd iv } \\
200 \mathrm{mg} \text { bid po }\end{array}$ & $\begin{array}{l}5 \text { days } \\
30 \text { days }\end{array}$ & Survived \\
\hline $\begin{array}{l}\text { Fungiscope } \\
-616\end{array}$ & Serbia & M & 19 & ALL (relapse) & Not neutropenic & BSI, pulmonary & Blood & Blood culture & $\begin{array}{l}\text { E: CFGN } \\
\text { T: CFGN }\end{array}$ & $\begin{array}{l}50 \mathrm{mg} \text { qd iv } \\
50 \mathrm{mg} \text { qd iv }\end{array}$ & $\begin{array}{l}4 \text { days } \\
34 \text { days }\end{array}$ & Died \\
\hline $\begin{array}{l}\text { Esposto } \\
\text { et al., } 2018\end{array}$ & Italy & $\begin{array}{l}M(11) \\
F(6) \\
\text { ns (1) }\end{array}$ & ns & $\begin{array}{l}\text { AML (8), } \\
\text { Hodgkin } \\
\text { lymphoma (3) } \\
\text { aplastic anemia } \\
\text { (2) } \\
\text { surgery (3), ns } \\
\text { (2) }\end{array}$ & ns & BSI & Blood & Blood culture & ns & ns & ns & Ns \\
\hline $\begin{array}{l}\text { Liu et al., } \\
2018\end{array}$ & China & M & 10 & $\begin{array}{l}\text { Acute } \\
\text { lymphocytic } \\
\text { leukemia }\end{array}$ & $\begin{array}{l}\text { Neutropenia, } \\
\text { pancreatitis }\end{array}$ & BSI, pulmonary & Blood & $\begin{array}{l}\text { Blood culture, } \\
\text { GM } 1.33,6.03 \text {, } \\
\text { beta-G } 746 \\
\mathrm{pg} / \mathrm{ml}\end{array}$ & $\begin{array}{l}\text { E: MFGN } \\
\text { T: VRZ } \\
\text { T: MFGN + VRZ } \\
\text { T: MFGN + L-AMB }\end{array}$ & $\begin{array}{l}50 \mathrm{mg} \text { qd iv } \\
150 \mathrm{mg} \text { iv } \mathrm{q} 12 \mathrm{~h} \\
100 \mathrm{mg} \text { qd iv }+100 \\
\mathrm{mg} \text { iv q12h } \\
27 \mathrm{mg} \text { iv qd }\end{array}$ & $\begin{array}{l}8 \text { days (mono) } \\
15 \text { days (mono) } \\
40 \text { days (MFGN + VRZ) } \\
43 \text { days (MFGN + L-AMB) }\end{array}$ & Survived \\
\hline $\begin{array}{l}\text { Salgüero } \\
\text { Fernández } \\
\text { et al., } 2018\end{array}$ & Spain & M & 47 & Lymphoma & $\begin{array}{l}\text { Neutropenia, } \\
\text { prednisone, } \\
\text { alloHSCT }\end{array}$ & BSI, skin & $\begin{array}{l}\text { Blood, skin } \\
\text { biopsy Brain } \\
\text { abscess }\end{array}$ & Blood culture & $\begin{array}{l}\text { T: L-AMB } \\
\text { T: 5FC }\end{array}$ & $\begin{array}{l}5 \mathrm{mg} / \mathrm{kg} / \mathrm{d} \\
37.5 \mathrm{mg} 4 \times \text { iv }\end{array}$ & $\begin{array}{l}60 \text { days } \\
60 \text { days }\end{array}$ & Died \\
\hline
\end{tabular}


TABLE 4 | Continued

\begin{tabular}{|c|c|c|c|c|c|c|c|c|c|c|c|c|}
\hline Study & Country & Sex & Age & $\begin{array}{l}\text { Underlying } \\
\text { disease }\end{array}$ & Risk factor ${ }^{\#}$ & Clinical form & $\begin{array}{l}\text { Positive } \\
\text { specimen }\end{array}$ & Lab diagnosis & Drug & Dosage & Duration & Outcome \\
\hline \multirow[t]{6}{*}{ This study } & \multirow[t]{6}{*}{ Czechia } & M & 45 & AML & $\begin{array}{l}\text { CVC, cytarabine, } \\
\text { neutropenia, } \\
\text { alloHSCT, acute } \\
\text { GvHD, } \\
\text { cholelithiasis, } \\
\text { cholecystectomy, } \\
\text { biliary drainage }\end{array}$ & $\begin{array}{l}\text { BSI, } \\
\text { disseminated }\end{array}$ & Blood & $\begin{array}{l}\text { Blood culture, } \\
\text { GM } 0.70 \\
(-2 \text { days })^{*}\end{array}$ & $\begin{array}{l}\text { T: AMB-D } \\
\text { T: VRZ }\end{array}$ & $\begin{array}{l}75 \mathrm{mg} \text { qd iv } \\
200 \mathrm{mg} \text { bid po }\end{array}$ & $\begin{array}{l}27 \text { days } \\
7 \text { days }\end{array}$ & Died \\
\hline & & $\mathrm{F}$ & 61 & AML & $\begin{array}{l}\text { CVC, cytarabine, } \\
\text { neutropenia, } \\
\text { chronic } \\
\text { pancreatitis, } \\
\text { cholelithiasis, } \\
\text { cholecystectomy }\end{array}$ & BSI & Blood & $\begin{array}{l}\text { Blood culture, } \\
\text { GM } 0.55 \\
(+3 \text { days)* }\end{array}$ & $\begin{array}{l}\text { T: AMB-D } \\
\text { T: AMB-LC }\end{array}$ & $\begin{array}{l}75 \mathrm{mg} \text { qd iv } \\
400 \mathrm{mg} \text { qd iv }\end{array}$ & $\begin{array}{l}15 \text { days } \\
6 \text { days }\end{array}$ & Died \\
\hline & & $\mathrm{F}$ & 63 & AML & $\begin{array}{l}\text { CVC, neutropenia } \\
\left(<500 \mathrm{~mm}^{3}\right) \text {, } \\
\text { cholelithiasis, } \\
\text { cholecystectomy, } \\
\text { cytarabine }\end{array}$ & BSI & Blood & $\begin{array}{l}\text { Blood culture, } \\
\text { GM 0.18, PCR } \\
\text { (sequencing) }\end{array}$ & $\begin{array}{l}\text { T: AMB-LC } \\
\text { T: VRZ }\end{array}$ & $\begin{array}{l}400 \mathrm{mg} \text { qd iv } \\
200 \mathrm{mg} \text { bid po }\end{array}$ & $\begin{array}{l}4 \text { days } \\
9 \text { days }\end{array}$ & Survived \\
\hline & & $\mathrm{F}$ & 58 & AML & $\begin{array}{l}\text { CVC, neutropenia } \\
\left(<500 \mathrm{~mm}^{3}\right) \text {, } \\
\text { cytarabine, } \\
\text { alloHSCT, acute } \\
\text { GVHD }\end{array}$ & $\begin{array}{l}\text { BSI, } \\
\text { pneumonia }\end{array}$ & Blood, rectum & $\begin{array}{l}\text { Blood culture, } \\
\text { GM } 0.50 \text { (only } \\
\text { with } 3^{\text {rd }} \text { blood } \\
\text { culture), PCR } \\
\text { (sequencing) }\end{array}$ & $\begin{array}{l}\text { T: AMB-D } \\
\text { T: AMB-LC } \\
\text { T: VRZ }\end{array}$ & $\begin{array}{l}50 \mathrm{mg} \text { qd iv } \\
400 \mathrm{mg} \text { qd iv } \\
200 \mathrm{mg} \text { bid po }\end{array}$ & $\begin{array}{l}2 \text { days } \\
7 \text { days } \\
4 \text { days (AMB-LC + VRZ) }\end{array}$ & Died \\
\hline & & $\mathrm{F}$ & 50 & AML & $\begin{array}{l}\text { CVC, cytarabine, } \\
\text { neutropenia, } \\
\text { autoHSCT }\end{array}$ & $\begin{array}{l}\text { BSI, } \\
\text { pneumonia }\end{array}$ & $\begin{array}{l}\text { Blood, wound } \\
\text { swab }\end{array}$ & Blood culture & T: AMB-D & $50 \mathrm{mg}$ qd iv & 4 days & Died \\
\hline & & $\mathrm{F}$ & 66 & Lymphoma & $\begin{array}{l}\text { CVC, cytarabine, } \\
\text { neutropenia, } \\
\text { cholelithiasis, } \\
\text { cholecystectomy, } \\
\text { Candida glabrata } \\
\text { fungemia }\end{array}$ & BSI & Blood, bile, urine & $\begin{array}{l}\text { Blood culture, } \\
\text { GM } 0.31\end{array}$ & $\begin{array}{l}\text { T: MFGN (C. glabrata } \\
\text { fungemia) } \\
\text { T: VRZ }\end{array}$ & $\begin{array}{l}100 \mathrm{mf} \text { qd iv } \\
200 \mathrm{mg} \text { bid po }\end{array}$ & $\begin{array}{l}12 \text { days (C. glabrata } \\
\text { fungemia) } \\
3 \text { days (S. clavata) }\end{array}$ & Died \\
\hline
\end{tabular}




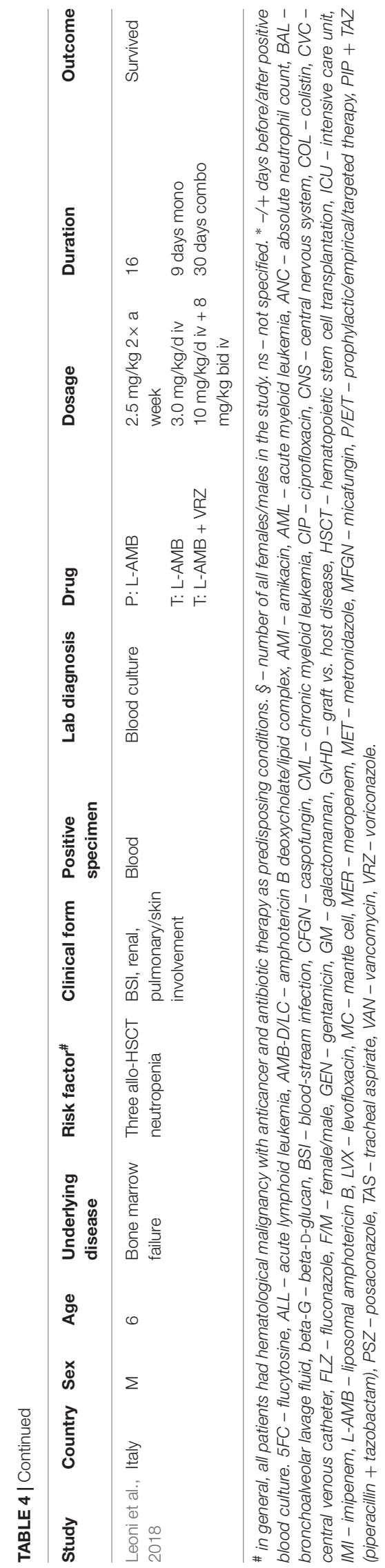

(Bonini et al., 2008; Schuermans et al., 2011; Liao et al., 2012b; Durán Graeff et al., 2017).

Voriconazole remains the drug of choice for S. clavata infections despite not all strains display optimal in vitro susceptibility results (see Patient No. 2, Table 1). This is in line with the recommendation from a panel of experts (Arendrup et al., 2014). On the other hand, liposomal amphotericin B may be an effective alternative; all three Italian patients responded to liposomal amphotericin B and two of them survived (the third died of another cause) (Del Principe et al., 2016). The use of combination therapy remains controversial. Voriconazole and liposomal amphotericin B have provided mixed successes. Adding flucytosine to those drugs as suggested by Lacroix's report and supported in vitro data could represent a potentially useful therapeutic modality for both (Tables 2-4) (Lacroix et al., 2007; Picard et al., 2014; Favre et al., 2016; Leoni et al., 2018; Liu et al., 2018). There are limited data about the therapeutic usefulness of posaconazole and isavuconazole (Miceli and Kauffman, 2015; Brunetti et al., 2016). Although the spectrum of activity of these antifungal drugs includes arthroconidial fungi, their MICs suggest that both drugs could be slightly less active on S. clavata than voriconazole, maybe, due to a lack of in vivo fungicidal activity and/or inadequate pharmacokinetics (Walsh et al., 1990; Girmenia et al., 2014; Pfaller et al., 2015; Durán Graeff et al., 2017; Esposto et al., 2018; Desnos-Ollivier et al., 2019). This may follow from variable host liver metabolizer status like in voriconazole (CYP2C19 gene polymorphism) or problematic bioavailability of oral suspension of posaconazole even when the latter problem can be overcome by new formulation of delayed release tablets (Owusu Obeng et al., 2014; Yi et al., 2017; Mason et al., 2019).

The two main pillars in successful management of infections caused by $S$. clavata are the early administration of antifungal drugs and the control of underlying conditions. While antifungal can safe life for a limited period of time, long-term survival is dependent on the recovery of the underlying hematological disease or neutropenia (Camus et al., 2014; Picard et al., 2014; Del Principe et al., 2016). The only of our six patient who survived achieved a complete hematopoietic regeneration and presented fewer risk factors (shorter period of deep neutropenia, no urinary catheter, no nasogastric tube, and no parenteral nutrition) with less severe symptomatology (lack of septic shock with MODS) (Table 1).

Recovery of $S$. clavata from the blood manifests dissemination stage of life-threatening infection and underlines the urgent need to move the timing of the institution of antifungal therapy before positivity of the blood culture. That supports empirical approach to the therapy using stratification of patients and to start initial treatment based on presence or the accumulation of risk factors, urgency of clinical situation, and availability of other laboratory and clinical data (antigen detection, imaging techniques, previous microbiological findings), including response to current therapy. Therefore, management of $S$. clavata infections is complex that requires close cooperation between the clinicians, microbiologists and epidemiologists.

Saprochaete clavata represents an emerging opportunistic fungal pathogen closely associated with AML. Most of the clinical and epidemiological characteristics overlap with the infections 
caused by other arthroconidial fungi, especially $M$. capitatus and T. asahii. Primary source of S. clavata is unknown but this yeast is able to colonize humans and under favorable conditions, such as deep and long immunosuppression, to overcome debilitated defense mechanisms and cause life-threatening infection. The prognosis of these invasive infections is generally poor due to lack of the specific clinical signs and symptoms, reliable diagnostic methods, and a limited efficacy of available antifungal drugs. The diagnosis of $S$. clavata infections is usually based on positivity of blood culture; detection of beta-D-glucan or Aspergillus galactomannan can be helpful. The optimal treatment has not been established yet; best results are connected with the application of voriconazole or liposomal amphotericin B, but successful outcome is usually critically dependent on the recovery of underlying conditions associated with immune dysfunction or deficiency.

\section{DATA AVAILABILITY STATEMENT}

The datasets generated for this study are available on request to the corresponding author.

\section{REFERENCES}

Arendrup, M. C., Boekhout, T., Akova, M., Meis, J. F., Cornely, O. A., Lortholary, O., et al. (2014). ESCMID and ECMM joint clinical guidelines for the diagnosis and management of rare invasive yeast infections. Clin. Microbiol. Infect. 20(Suppl. 3), 76-98. doi: 10.1111/1469-0691.12360

Armstrong-James, D., Bicanic, T., Brown, G. D., Hoving, J. C., Meintjes, G., Nielsen, K., et al. (2017). AIDS-related mycoses: current progress in the field and future priorities. Trends Microbiol. 25, 428-430. doi: 10.1016/j.tim.2017.02.013

Auchtung, T. A., Fofanova, T. Y., Stewart, C. J., Nash, A. K., Wong, M. C., Gesell, J. R., et al. (2018). Investigating colonization of the healthy adult gastrointestinal tract by fungi. $m$ Sphere 3:e00092-18. doi: 10.1128/mSphere.00092-18

Banjara, N., Suhr, M. J., and Hallen-Adams, H. E. (2015). Diversity of yeast and mold species from a variety of cheese types. Curr. Microbiol. 70, 792-800. doi: 10.1007/s00284-015-0790-791

Bonifaz, A., Vázquez-González, D., Macías, B., Paredes-Farrera, F., Hernández, M. A., Araiza, J., et al. (2010). Oral geotrichosis: report of 12 cases. J. Oral Sci. 52, 477-483. doi: 10.4103/0973-029X.157210

Bonini, A., Capatti, C., Parmeggiani, M., Gugliotta, L., Micozzi, A., Gentile, G., et al. (2008). Galactomannan detection in Geotrichum capitatum invasive infections: report of 2 new cases and review of diagnostic options. Diagn. Microbiol. Infect. Dis. 62, 450-452. doi: 10.1016/j.diagmicrobio.2008.08.008

Bouakline, A., Lacroix, C., Roux, N., Gangneux, J. P., and Derouin, F. (2000). Fungal contamination of food in hematology units. J. Clin. Microbiol. 38, 4272-4273.

Bougnoux, M. E., Brun, S., and Zahar, J. R. (2018). Healthcare-associated fungal outbreaks: new and uncommon species, new molecular tools for investigation and prevention. Antimicrob. Resist. Infect. Control 7:45. doi: 10.1186/s13756018-0338-339

Brunetti, G., Visconti, V., Ghezzi, M. C., Mantovani, S., Ferretti, G., and Raponi, G. (2016). Management and treatment of magnusiomyces capitatus (Geotrichum capitatum) pleural infection in a non-neutropenic patient with posaconazole. A new therapeutic opportunity? New Microbiol. 39, 307-309.

Camus, V., Thibault, M. L., David, M., Gargala, G., Compagnon, P., Lamoureux, F., et al. (2014). Invasive Geotrichum clavatum fungal infection in an acute myeloid leukaemia patient: a case report and review. Mycopathologia 177, 319-324. doi: 10.1007/s11046-014-9746-4

Christakis, G., Perlorentzou, S., Aslanidou, M., Megalakaki, A., and Velegraki, A. (2005). Fatal blastoschizomyces capitatus sepsis in a neutropenic patient

\section{AUTHOR CONTRIBUTIONS}

VB contributed conception and design of the study, analyzed and interpreted the patient and microbiological data, and wrote the manuscript. RB analyzed and interpreted the patient data regarding molecular analysis. EH analyzed and interpreted the patient data regarding the hematological disease. OC and DS reviewed the manuscript and provided FungiScope data. $\mathrm{PZZ}$ analyzed and interpreted the patient data regarding the hematological disease and wrote the manuscript. All authors contributed to manuscript revision, read and approved the submitted version.

\section{FUNDING}

This work was supported by program PROGRES Q40/08.

\section{ACKNOWLEDGMENTS}

We thank Cyrus Rasti, M.D. for language editing.

with acute myeloid leukemia: first documented case from Greece. Mycoses 48, 216-220. doi: 10.1111/j.1439-0507.2005.01098.x

CLSI (2009). Method for Antifungal Disk Diffusion Susceptibility Testing of Yeasts; Approved Guideline- CLSI Document M44-A2, 2nd Edn. Wayne, PA: Clinical and Laboratory Standards Institute.

Colombo, A. L., de Almeida Júnior, J. N., Slavin, M. A., Chen, S. C., and Sorrell, T. C. (2017). Candida and invasive mould diseases in non-neutropenic critically ill patients and patients with haematological cancer. Lancet Infect. Dis. 17, e344-e356. doi: 10.1016/S1473-3099(17)30304-3

Cornely, O. A., Gachot, B., Akan, H., Bassetti, M., Uzun, O., Kibbler, C., et al. (2015). Epidemiology and outcome of fungemia in a cancer cohort of the infectious diseases group (IDG) of the european organization for research and treatment of cancer (EORTC 65031). Clin. Infect. Dis. 61, 324-331. doi: 10.1093/ $\mathrm{cid} / \mathrm{civ} 293$

Daniel, H. M., Lachance, M. A., and Kurtzman, C. P. (2014). On the reclassification of species assigned to candida and other anamorphic ascomycetous yeast genera based on phylogenetic circumscription. Antonie Van Leeuwenhoek 106, 67-84. doi: 10.1007/s10482-014-0170-z

de Almeida Júnior, J. N., and Hennequin, C. (2016). Invasive Trichosporon infection: a systematic review on a re-emerging fungal pathogen. Front. Microbiol. 7:1629. doi: 10.3389/fmicb.2016.01629

de Almeida Júnior, J. N., Sztajnbok, J., da Silva, A. R., Vieira, V. A., Galastri, A. L., Bissoli, L., et al. (2016). Rapid identification of moulds and arthroconidial yeasts from positive blood cultures by MALDI-TOF mass spectrometry. Med. Mycol. 54, 885-889. doi: 10.1128/JCM.01640-1

De Hoog, G., and Smith, M. (2004). Ribosomal gene phylogeny and species delimitation in Geotrichum and its teleomorphs. Stud. Mycol. 50, 489-515.

de Hoog, G. S., Smith, M. T., and Guého, E. (1986). A revision of the genus geotrichurn in its teleomorphs. Stud. Mycol. 29, 1-131.

De Pauw, B., Walsh, T. J., Donnelly, J. P., Stevens, D. A., Edwards, J. E., Calandra, T., et al. (2008). Revised definitions of invasive fungal disease from the european organization for research and treatment of cancer/invasive fungal infections cooperative group and the national institute of allergy and infectious diseases mycoses study group (EORTC/MSG) consensus group. Clin. Infect. Dis. 46, 1813-1821. doi: 10.1086/588660

Del Principe, M. I., Sarmati, L., Cefalo, M., Fontana, C., De Santis, G., Buccisano, F., et al. (2016). A cluster of Geotrichum clavatum (Saprochaete clavata) infection in haematological patients: a first Italian report and review of literature. Mycoses 59, 594-601. doi: $10.1111 /$ myc. 12508 
Desnos-Ollivier, M., Blanc, C., Garcia-Hermoso, D., Hoinard, D., Alanio, A., and Dromer, F. (2014). Misidentification of Saprochaete clavata as Magnusiomyces capitatus in clinical isolates: utility of internal transcribed spacer sequencing and matrix-assisted laser desorption ionization-time of flight mass spectrometry and importance of reliable databases. J. Clin. Microbiol. 52, 2196-2198. doi: 10.1128/JCM.00039-14

Desnos-Ollivier, M., Bretagne, S., Boullié, A., Gautier, C., Dromer, F., Lortholary, O., et al. (2019). Isavuconazole MICs distribution of 29 yeast species responsible for invasive infections (2015-2017). Clin. Microbiol. Infect. 25, 634.e1-634.e4. doi: 10.1016/j.cmi.2019.02.007

Durán Graeff, L., Seidel, D., Vehreschild, M. J., Hamprecht, A., Kindo, A., Racil, Z., et al. (2017). Invasive infections due to Saprochaete and Geotrichum species: report of 23 cases from the fungiscope registry. Mycoses 60, 273-279. doi: $10.1111 /$ myc. 12631

Esposto, M. C., Prigitano, A., Lo Cascio, G., Ossi, C., Grancini, A., Cavanna, C., et al. (2018). Yeast-like filamentous fungi: molecular identification and in vitro susceptibility study. Med. Mycol. 57, 909-913. doi: 10.1093/mmy/myy133

Favre, S., Rougeron, A., Levoir, L., Pérard, B., Milpied, N., Accoceberry, I., et al. (2016). Saprochaete clavata invasive infection in a patient with severe aplastic anemia: efficacy of voriconazole and liposomal amphotericin B with adjuvant granulocyte transfusions before neutrophil recovery following allogeneic bone marrow transplantation. Med. Mycol. Case Rep. 11, 21-23. doi: 10.1016/j.mmcr. 2016.03.001

Fernández-Ruiz, M., Guinea, J., Puig-Asensio, M., Zaragoza, Ó, Almirante, B., Cuenca-Estrella, M., et al. (2017). Fungemia due to rare opportunistic yeasts: data from a population-based surveillance in spain. Med. Mycol. 55, 125-136. doi: $10.1093 / \mathrm{mmy} / \mathrm{myw} 055$

Gadea, I., Cuenca-Estrella, M., Prieto, E., Diaz-Guerra, T. M., Garcia-Cia, J. I., Mellado, E., et al. (2004). Genotyping and antifungal susceptibility profile of Dipodascus capitatus isolates causing disseminated infection in seven hematological patients of a tertiary hospital. J. Clin. Microbiol. 42, 1832-1836. doi: 10.1128/JCM00039-14

García-Ruiz, J. C., López-Soria, L., Olazábal, I., Amutio, E., Arrieta-Aguirre, I., Velasco-Benito, V., et al. (2013). Invasive infections caused by Saprochaete capitata in patients with haematological malignancies: report of five cases and review of the antifungal therapy. Rev. Iberoam. Micol. 30, 248-255. doi: 10.1016/ j.riam.2013.02.004

Girmenia, C., Barosi, G., Piciocchi, A., Arcese, W., Aversa, F., Bacigalupo, A., et al. (2014). Primary prophylaxis of invasive fungal diseases in allogeneic stem cell transplantation: revised recommendations from a consensus process by gruppo italiano trapianto midollo osseo (GITMO). Biol. Blood Marrow Transplant. 20, 1080-1088. doi: 10.1016/j.bbmt.2014.02.018

Girmenia, C., Pagano, L., Martino, B., D’Antonio, D., Fanci, R., Specchia, G., et al. (2005). Invasive infections caused by Trichosporon species and Geotrichum capitatum in patients with hematological malignancies: a retrospective multicenter study from Italy and review of the literature. J. Clin. Microbiol. 43, 1818-1828. doi: 10.1128/JCM.43.4.1818-1828.2005

Gouba, N., and Drancourt, M. (2015). Digestive tract mycobiota: a source of infection. Med. Mal. Infect. 45, 9-16. doi: 10.1016/j.medmal.2015.01.007

Gouba, N., Raoult, D., and Drancourt, M. (2014). Eukaryote culturomics of the gut reveals new species. PLoS One 9:e106994. doi: 10.1371/journal.pone.0106994

Guého, E., de Hoog, G. S., Smith, M. T., and Meyer, S. A. (1987). DNA relatedness, taxonomy, and medical significance of Geotrichum capitatum. J. Clin. Microbiol. 25, 1191-1194.

Guinan, J., Villa, P., and Thangamani, S. (2018). Secondary bile acids inhibit candida albicans growth and morphogenesis. Pathog. Dis. 1:76. doi: 10.1093/ femspd/fty038

Gulcan, A., Gulcan, E., Keles, M., and Aktas, E. (2016). Oral yeast colonization in peritoneal dialysis and hemodialysis patients and renal transplant recipients. Comp. Immunol. Microbiol. Infect. Dis. 46, 47-52. doi: 10.1016/j.cimid.2016.04. 004

Gurgui, M., Sanchez, F., March, F., Lopez-Contreras, J., Martino, R., Cotura, A., et al. (2011). Nosocomial outbreak of Blastoschizomyces capitatus associated with contaminated milk in a haematological unit. J. Hosp. Infect. 78, 274-278. doi: 10.1016/j.jhin.2011.01.027

Hallen-Adams, H. E., and Suhr, M. J. (2017). Fungi in the healthy human gastrointestinal tract. Virulence 8, 352-358. doi: 10.1080/21505594.2016. 1247140
Hawksworth, D. L., Crous, P. W., Redhead, S. A., Reynolds, D. R., Samson, R. A., Seifert, K. A., et al. (2011). The amsterdam declaration on fungal nomenclature. IMA Fungus 2, 105-112. doi: 10.5598/imafungus.2011.02.01.14

Hazen, K. C. (1995). New and emerging yeast pathogens. Clin. Microbiol. Rev. 8, 462-478. doi: $10.1128 / \mathrm{cmr} .8 .4 .462$

Henrich, T. J., Marty, F. M., Milner, D. A. Jr., and Thorner, A. R. (2009). Disseminated Geotrichum candidum infection in a patient with relapsed acute myelogenous leukemia following allogeneic stem cell transplantation and review of the literature. Transpl. Infect. Dis. 11, 458-462. doi: 10.1111/j.13993062.2009.00418.x

Kaplan, E., Al-Hatmi, A. M. S., Ilkit, M., Gerrits van den Ende, A. H. G., Hagen, F., Meis, J. F., et al. (2017). Molecular diagnostics of arthroconidial yeasts, frequent pulmonary opportunists. J. Clin. Microbiol. 56:e01427-17. doi: 10.1128/JCM. 01427-17

Kelly, C. P., Chong Nguyen, C., Palmieri, L. J., Pallav, K., Dowd, S. E., Humbert, L., et al. (2019). Saccharomyces boulardii CNCM I-745 modulates the fecal bile acids metabolism during antimicrobial therapy in healthy volunteers. Front. Microbiol. 10:336. doi: 10.3389/fmicb.2019.00336

Kolecka, A., Khayhan, K., Groenewald, M., Theelen, B., Arabatzis, M., Velegraki, A., et al. (2013). Identification of medically relevant species of arthroconidial yeasts by use of matrix-assisted laser desorption ionization-time of flight mass spectrometry. J. Clin. Microbiol. 51, 2491-2500. doi: 10.1128/JCM.00470-13

Lacroix, C., Brethon, B., Boissel, N., Desnos, M., Leblanc, T., Raffoux, E., et al. (2007). Geotrichum clavatum an emerging pathogen responsible for invasive infection in two neutropenic leukemia patients [abstract P180]. J. Chemother. 19(Suppl. 3):81.

Leoni, M., Riccardi, N., Rotulo, G. A., Godano, E., Faraci, M., Bandettini, R., et al. (2018). Magnusiomyces clavatus infection in a child after allogeneic hematotopoetic stem cell transplantation: diagnostic and therapeutic implications. Med. Mycol. Case Rep. 23, 65-67. doi: 10.1016/j.mmcr.2018. 12.005

Li, J., Chen, D., Yu, B., He, J., Zheng, P., Mao, X., et al. (2018). Fungi in gastrointestinal tracts of human and mice: from community to functions. Microb. Ecol. 75, 821-829. doi: 10.1007/s00248-017-1105-9

Liao, Y., Hartmann, T., Ao, J. H., and Yang, R. Y. (2012a). Serum glucuronoxylomannan may be more appropriate for the diagnosis and therapeutic monitoring of Trichosporon fungemia than serum $\beta$-D-glucan. Int. J. Infect. Dis. 16:e638. doi: 10.1016/j.ijid.2012.03.009

Liao, Y., Hartmann, T., Zheng, T., Yang, R. Y., Ao, J. H., and Wang, W. L. (2012b). Breakthrough Trichosporonosis in patients receiving echinocandins: case report and literature review. Chin. Med. J. 125, 2632-2635.

Liu, X., Zhou, W., Jiang, Y., and Kuang, L. (2018). Invasive fungal infection caused by Geotrichum clavatum in an acute leukemia child: first documented case from mainland China. JPN J. Infect. Dis. 72, 130-132. doi: 10.7883/yoken

Mason, M. J., McDaneld, P. M., Musick, W. L., and Kontoyiannis, D. P. (2019). Serum levels of crushed posaconazole delayed release tablets. Antimicrob. Agents Chemother. 63:e02688-18. doi: 10.1128/AAC.02688-18

Meletiadis, J., and Roilides, E. (2013). Rare invasive fungal infections: epidemiology, diagnosis and management. Curr. Infect. Dis. Rep. 7, 351-360. doi: 10.1007/s12281-013-0155-9

Miceli, M. H., Díaz, J. A., and Lee, S. A. (2011). Emerging opportunistic yeast infections. Lancet Infect. Dis. 11, 142-151. doi: 10.1016/S1473-3099(10)7021870218

Miceli, M. H., and Kauffman, C. A. (2015). Isavuconazole: a new broad-spectrum triazole antifungal agent. Clin. Infect. Dis. 61, 1558-1565. doi: 10.1093/cid/ civ571

Millar, B. C., Xu, J., Moore, J. E., and Earle, J. A. P. (2000). A simple and sensitive method to extract bacterial, yeast and fungal DNA from blood culture material. J. Microb. Meth. 42, 139-147. doi: 10.1016/s0167-7012(00) 00174-3

Nakase, K., Suzuki, K., Kyo, T., Kohara, T., Sugawara, Y., and Katayama, N. (2012). Is elevation of the serum $\beta$-D-glucan level a paradoxical sign for Trichosporon fungemia in patients with hematologic disorders? Int. J. Infect. Dis. 16, e2-e4. doi: 10.1016/j.ijid.2011.09.017

Odabasi, Z., Paetznick, V. L., Rodriguez, J. R., Chen, E., McGinnis, M. R., and Ostrosky-Zeichner, L. (2006). Differences in beta-glucan levels in culture supernatants of a variety of fungi. Med. Mycol. 44, 267-272. doi: 10.1080/ 13693780500474327 
Owusu Obeng, A., Egelund, E. F., Alsultan, A., Peloquin, C. A., and Johnson, J. A. (2014). CYP2C19 polymorphisms and therapeutic drug monitoring of voriconazole: are we ready for clinical implementation of pharmacogenomics? Pharmacotherapy 34, 703-718. doi: 10.1002/phar.1400

Pfaller, M. A., Rhomberg, P. R., Messer, S. A., Jones, R. N., and Castanheira, M. (2015). Isavuconazole, micafungin, and 8 comparator antifungal agents' susceptibility profiles for common and uncommon opportunistic fungi collected in 2013: temporal analysis of antifungal drug resistance using CLSI species-specific clinical breakpoints and proposed epidemiological cutoff values. Diagn. Microbiol. Infect. Dis. 82, 303-313. doi: 10.1016/j.diagmicrobio. 2015.04.008

Picard, M., Cassaing, S., Letocart, P., Verdeil, X., Protin, C., Chauvin, P., et al. (2014). Concomitant cases of disseminated Geotrichum clavatum infections in patients with acute myeloid leukemia. Leuk. Lymphoma 55, 1186-1188. doi: 10.3109/10428194.2013.820290

Pimenta, R. S., Alves, P. D., Almeida, G. M., Silva, J. F., Morais, P. B., Corrêa, A. Jr., et al. (2009). Yeast communities in two atlantic rain forest fragments in southeast Brazil. Braz. J. Microbiol. 40, 90-95. doi: 10.1590/S15178382009000100015

Posteraro, B., Efremov, L., Leoncini, E., Amore, R., Posteraro, P., Ricciardi, W., et al. (2015). Are the conventional commercial yeast identification methods still helpful in the era of new clinical microbiology diagnostics? a meta-analysis of their accuracy. J. Clin. Microbiol. 53, 2439-2450. doi: 10.1128/JCM.00 802-15

Repetto, E. C., Giacomazzi, C. G., and Castelli, F. (2012). Hospital-related outbreaks due to rare fungal pathogens: a review of the literature from 1990 to June 2011. Eur. J. Clin. Microbiol. Infect. Dis. 31, 2897-2904. doi: 10.1007/ s10096-012-1661-3

Salgüero Fernández, I., Nájera Botello, L., Orden Martinez, B., and Roustan Gullón, G. (2018). Disseminated fungemia by Saprochaete clavata. Enferm. Infecc. Microbiol. Clin. 37, 283-284. doi: 10.1016/j.eimc.2018.05.003

Schiemann, R., Glasmacher, A., Bailly, E., Horré, R., Molitor, E., Leutner, C., et al. (1998). Geotrichum capitatum septicaemia in neutropenic patients: case report and review of the literature. Mycoses 41, 113-116. doi: 10.1111/j.1439-0507. 1998.tb00311.x

Schuermans, C., van Bergen, M., Coorevits, L., Verhaegen, J., Lagrou, K., Surmont, I., et al. (2011). Breakthrough Saprochaete capitata infections in patients receiving echinocandins: case report and review of the literature. Med. Mycol. 49, 414-418. doi: 10.3109/13693786.2010.535179

Seidel, D., Durán Graeff, L. A., Vehreschild, M. J. G. T., Wisplinghoff, H., Ziegler, M., Vehreschild, J. J., et al. (2017). FungiScope ${ }^{\mathrm{TM}}$-global emerging fungal infection registry. Mycoses 60, 508-516. doi: 10.1111/myc.12631

Seyfarth, F., Wiegand, C., Erhard, M., Gräser, Y., Elsner, P., and Hipler, U. C. (2012). Identification of yeast isolated from dermatological patients by MALDITOF mass spectrometry. Mycoses 55, 276-280. doi: 10.1111/j.1439-0507.2011. 02086.x

Smith, M. T., and Poot, G. A. (1998). Dipodascus capitatus, dipodascus spicifer and Geotrichum clavatum: genomic characterization. Antonie Van Leeuwenhoek 74, 229-235.

Stentoft, J. (1990). The toxicity of cytarabine. Drug Saf. 5, 7-27. doi: 10.2165/ 00002018-199005010-00003

Sun, W., Su, J., Xu, S., and Yan, D. (2012). Trichosporon asahii causing nosocomial urinary tract infections in intensive care unit patients: genotypes, virulence factors and antifungal susceptibility testing. J. Med. Microbiol. 61, 1750-1757. doi: 10.1099/jmm.0.049817-0

Theriot, C. M., Bowman, A. A., and Young, V. B. (2016). Antibiotic-induced alterations of the gut microbiota alter secondary bile acid production and allow for clostridium difficile spore germination and outgrowth in the large intestine. mSphere 1:e00045-15. doi: 10.1128/mSphere.00045-15

Trabelsi, H., Néji, S., Gargouri, L., Sellami, H., Guidara, R., Cheikhrouhou, F., et al. (2015). Geotrichum capitatum septicemia: case report and review of the literature. Mycopathologia 179, 465-469. doi: 10.1007/s11046-015-9869-2

Vallabhaneni, S., Benedict, K., Derado, G., and Mody, R. K. (2017). Trends in hospitalizations related to invasive aspergillosis and mucormycosis in the United States, 2000-2013. Open Forum Infect. Dis. 4:ofw268. doi: 10.1093/ofid/ ofw268

Vallabhaneni, S., and Chiller, T. M. (2016). Fungal infections and new biologic therapies. Curr. Rheumatol. Rep. 18:29. doi: 10.1007/s11926-016-0572-571

Vallabhaneni, S., Mody, R. K., Walker, T., and Chiller, T. (2016). The global burden of fungal diseases. Infect. Dis. Clin. North Am. 30, 1-11. doi: 10.1016/j.idc.2015. 10.004

Vaux, S., Criscuolo, A., Desnos-Ollivier, M., Diancourt, L., Tarnaud, C., Vandenbogaert, M., et al. (2014). Multicenter outbreak of infections by Saprochaete clavata, an unrecognized opportunistic fungal pathogen. mBio 5, e2309-e2314. doi: 10.1128/mBio.02309-2314

Walsh, T. J., Melcher, G. P., Rinaldi, M. G., Lecciones, J., McGough, D. A., Kelly, P., et al. (1990). Trichosporon beigelii, an emerging pathogen resistant to amphotericin B. J. Clin. Microbiol. 28, 1616-1622.

Wang, W., Wang, J., Li, J., Yan, P., Jin, Y., Zhang, R., et al. (2018). Cholecystectomy damages aging-associated intestinal microbiota construction. Front. Microbiol. 9:1402. doi: 10.3389/fmicb.2018.01402

Willemze, R., Suciu, S., Meloni, G., Labar, B., Marie, J. P., Halkes, C. J., et al. (2014). High-dose cytarabine in induction treatment improves the outcome of adult patients younger than age 46 years with acute myeloid leukemia: results of the EORTC-GIMEMA AML-12 trial. J. Clin. Oncol. 32, 219-228. doi: 10.1200/JCO.2013.51.8571

Yi, W. M., Schoeppler, K. E., Jaeger, J., Mueller, S. W., MacLaren, R., Fish, D. N., et al. (2017). Voriconazole and posaconazole therapeutic drug monitoring: a retrospective study. Ann. Clin. Microbiol. Antimicrob. 16:60. doi: 10.1186/ s12941-017-0235-238

Zalar, P., Novak, M., de Hoog, G. S., and Gunde-Cimerman, N. (2011). Dishwashers-a man-made ecological niche accommodating human opportunistic fungal pathogens. Fungal Biol. 115, 997-1007. doi: 10.1016/j.funbio.2011.04.007

Conflict of Interest: The authors declare that the research was conducted in the absence of any commercial or financial relationships that could be construed as a potential conflict of interest.

Copyright (c) 2019 Buchta, Bolehovská, Hovorková, Cornely, Seidel and Žák. This is an open-access article distributed under the terms of the Creative Commons Attribution License (CC BY). The use, distribution or reproduction in other forums is permitted, provided the original author(s) and the copyright owner(s) are credited and that the original publication in this journal is cited, in accordance with accepted academic practice. No use, distribution or reproduction is permitted which does not comply with these terms. 